\title{
Financial Sector Linkages and the Dynamics of Bank and Sovereign Credit Spreads
}

\author{
Kallestrup, René; Lando, David; Murgoci, Agatha
}

\author{
Document Version \\ Final published version \\ Published in: \\ Journal of Empirical Finance \\ DOI: \\ 10.1016/j.jempfin.2016.01.004 \\ Publication date: \\ 2016 \\ License \\ CC BY-NC-ND
}

Citation for published version (APA):

Kallestrup, R., Lando, D., \& Murgoci, A. (2016). Financial Sector Linkages and the Dynamics of Bank and Sovereign Credit Spreads. Journal of Empirical Finance, 38(Part A), 374-393.

https://doi.org/10.1016/j.jempfin.2016.01.004

Link to publication in CBS Research Portal

\section{General rights}

Copyright and moral rights for the publications made accessible in the public portal are retained by the authors and/or other copyright owners and it is a condition of accessing publications that users recognise and abide by the legal requirements associated with these rights.

\section{Take down policy}

If you believe that this document breaches copyright please contact us (research.lib@cbs.dk) providing details, and we will remove access to the work immediately and investigate your claim. 


\title{
Financial sector linkages and the dynamics of bank and sovereign credit spreads 访
}

\author{
René Kallestrup ${ }^{a}$, David Lando ${ }^{\mathrm{b}, *}$, Agatha Murgoci ${ }^{\mathrm{c}}$ \\ a Capital Four Management A/S, Denmark \\ b Department of Finance, Copenhagen Business School, Solbjerg Plads 3, DK-2000 Frederiksberg, Denmark \\ c Department of Economics, Aarhus BSS, Aarhus University, Denmark
}

\section{A R T I C L E I N F O}

\section{Article history:}

Received 29 May 2015

Received in revised form 9 December 2015

Accepted 5 January 2016

Available online 12 January 2016

\section{JEL classification:}

G01

G15

G21

Keywords:

Credit risk

Banks

Sovereign risk

\begin{abstract}
A B S T R A C T
We show that CDS premiums of sovereigns are significantly affected by the foreign exposures of their domestic banks. Our analysis uses a simple risk-weighted exposure measure which aggregates detailed data on the composition and risk of banks' foreign exposures. A 1 basis point change in our risk weighted exposure measure corresponds to an average change of approximately $0.4 \mathrm{bp}$ in sovereign CDS spreads. Extensive robustness checks confirm that the explanatory power of our measure is not due to common factors in CDS premiums. We also measure the size and riskiness of the sovereign's implicit and explicit guarantees extended to its domestic banking system.

(C) 2016 The Authors. Published by Elsevier B.V. This is an open access article under the CC BY-NC-ND license
\end{abstract} (http://creativecommons.org/licenses/by-nc-nd/4.0/).

\section{Introduction}

The European debt crisis has again demonstrated the importance of bank risk for the understanding of sovereign risk. But to what extent is the effect of the risk of the local banking system measurable in the dynamics of sovereign CDS spreads? In this paper, we use BIS consolidated banking statistics to construct a simple risk-weighted measure of foreign exposures of a banking system and apply it to data from 17 countries. Our measure shows how the size and riskiness of foreign asset holdings of the largest banks are an important determinant, not only of their own CDS premiums but also of the CDS premiums of the sovereign in which the banks reside. Extensive robustness checks confirm that the significance of our measure cannot be attributed to common variation in CDS spreads. We find that our exposure measure is significant in explaining sovereign CDS premiums even after including global CDS indices as explanatory variables.

\footnotetext{
it We thank Erika Jimenez and Jing Zhang of Moody's Analytics for providing us with EDF data. We are grateful to Pierluigi Balduzzi, Barbara Casu, Andrew Karolyi, Karen Lewis, Jean-Stéphane Mésonnier, Mads Stenbo Nielsen,Thierry Roncalli, Andreas Stathopoulos, Gustavo Suarez, Haoxiang Zhu, Lasse Heje Pedersen, Christian Wagner, and seminar participants at Bocconi, Copenhagen Business School, University of Illinois at Urbana-Champaign, Stockholm School of Economics, Sveriges Riksbank, Danmarks Nationalbank, Tilburg University, University of Southern Denmark, ISEG Technical University of Lisbon, LUISS, and participants at the Conference on Systemic Risk and Data Issues, The Darla Moore School of Business Inaugural Fixed Income Conference, Financial Risks International Forum in Paris, The International Conference on C.R.E.D.I.T., The McGill Global Asset Management Conference, EFA, WFA and the European Sovereign Debt Crisis Conference for valuable suggestions. Lando and Murgoci acknowledge support from the Danish Social Science Research Council and through their affiliation with the Center for Financial Frictions (FRIC) under grant no. DNRF102 from the Danish National Research Foundation. Kallestrup acknowledges support from Danmarks Nationalbank.

* Corresponding author.
}

E-mail addresses: rene.kallestrup@capital-four.com (R. Kallestrup), dl.fi@cbs.dk (D. Lando), agatha.murgoci@econ.au.dk (A. Murgoci). 
Our measure is useful not only because it is simple to compute, but also in that it provides an exogenous source of variation of bank credit risk, which is not affected by the risk of the sovereign in which the bank resides. In other words, while our measure is clearly capturing an important source of credit risk of the bank, it has the advantage that the resulting effect on the sovereign does not give rise to a direct feedback loop from the sovereign back to the bank. This is because we focus on the foreign exposures. The effect of foreign exposures of domestic banks is economically significant in that a one standard deviation change in our risk exposure measure changes sovereign CDS spreads on average by $24 \mathrm{bp}$, which amounts to a quarter of the average standard deviation for sovereign CDS in our sample. Longstaff et al. (2011) argue that the influence of the US equity and high yield markets on sovereign CDS premiums dominates that of the local stock market. Our results suggest that the risk from the local banking system should be included as a significant local factor. This local risk factor remains significant when we include a global sovereign CDS index, whereas the effect from the US market then disappears.

The risk of the banks as measured by our exposure measure is likely to affect sovereign CDS spreads through implicit or explicit guarantees of the banking system. To explore this, we combine information on the size of the banking system relative to GDP with the riskiness measured both through CDS premiums and bank EDFs. These measures of the size and risk of the guarantees greatly influence sovereign CDS premia, even after controlling for traditional local fiscal measures and global factors.

While our measure is shown to be important for sovereign CDS spreads, we focus also more directly on its impact on bank CDS spreads because of the clear policy implications. In its 2011/2012 so-called capital exercises, the European Banking Authority put a heavy emphasis on bank holdings of sovereign debt with a particular focus on exposures to the so-called GIIPS countries. These exercises were conducted in order to assess the need for additional bank capital buffers. It is worth noting, however, that foreign private exposures are actually a much larger source of foreign exposures of banks. For a large sample of European countries, the private exposures to GIIPS countries in late 2010 were between 4 and 10 times higher than the exposures to GIIPS sovereign debt. ${ }^{1}$ Hence, an increased focus on the foreign private exposures in stress tests is clearly warranted.

\section{Related literature}

There is an extensive literature on the determinants of sovereign CDS spreads and we refer to Augustin (forthcoming) for a review of the rapidly growing literature. Our empirical specification includes local and global factors found in Longstaff et al. (2011). There, the authors show large commonality with the first principal component explaining $75 \%$ of variations in sovereign CDS spreads in the period 2007-2010. Most of the commonality in their study is driven by global factors, risk premiums and investment flows rather than local factors. In our sample, the assets of the banking system are on average three times the size of the country's GDP. It is therefore not surprising that in spite of solid macroeconomic fundamentals, the risk of the banking system significantly impacts sovereign CDS premia. Reinhart and Rogoff (2009) provide a thorough account of the role of bank risk in explaining sovereign crises in their comprehensive treatment of financial crises through eight centuries. Reinhart and Rogoff (2011) document the link between the banking crisis and sovereign default in different countries in a historical perspective.

There is also an extensive literature on how sovereign risk may affect the risk of banks. Gennaioli et al. (2014) provide theoretical underpinnings and evidence for the transmission of a sovereign debt crisis to the banking system and the real economy, through the banks' holdings of sovereign debt.

The fact that risk may flow in both directions between sovereigns and domestic banks gives rise to possible feedback loops and this issue is treated thoroughly in Acharya et al. (2015) and in Bolton and Jeanne (2011). Acharya et al. (2015) also carry out an empirical study and our study supplements this in several important aspects. We show that the private exposures of banks - both foreign and domestic - are fundamental to understanding sovereign risk, and not just the bank holdings of foreign and domestic sovereign bonds. ${ }^{2}$ The bulk of banks' foreign exposures is to the private sector and not to sovereigns. This is important, in light of the fact alluded to above that for European countries in our sample, the private exposures to GIIPS countries are much higher in late 2010 than their exposures to sovereign debt. Our focus on the total exposure is also in contrast with Acharya and Steffen (2015), whose main focus is on holdings of sovereign debt. We also supplement the empirical evidence by measuring the riskiness of the exposure both through CDS premiums and EDFs. The large total foreign exposures of banks provide a part of the explanation for the finding of Ang and Longstaff (2013) that sovereign risk seems to flow through the financial markets rather than being directly rooted in macroeconomic fundamentals.

There are other studies focusing on how foreign bank exposures may cause risk to spread across banking systems. Tressel (2010) models the deleveraging of banks in countries whose banks have been exposed to losses in another country. In his calibration, Tressel (2010) also uses the consolidated banking statistics from BIS but he does not focus on the detailed time series of these statistics. Degryse et al. (2010) also use BIS consolidated banking statistics as a basis for simulating how shocks to one country's banking system may propagate through the international linkages and cause contagious defaults. Their focus is not on CDS spreads and their data end in 2006, whereas we cover the current financial crisis all through the end of 2010.

Whether contagion through networks of exposures survives as explanatory variables, once global common factors have been accounted for, is not widely agreed upon. For example, Eichengreen et al. (2012) use dynamic principal component analysis to identify common latent factors underlying the dynamics of CDS premiums for 45 banks in the USA and 8 European countries. In

\footnotetext{
1 The underlying data are available by request.

2 A recent version of Acharya et al. (2015) has included a measure similar to our BIS measure.
} 
their analysis of all possible combinations of pairwise influences, they find a very limited role of direct contagion. Our riskweighted aggregate measure of foreign bank exposure survives even after correcting for observable common factors, but it is not a contagion measure in that the measured exposures are not primarily to other banks. Rose and Spiegel (2010) find "remarkably little evidence that the intensity of the crisis across countries can be easily modeled using quantitative techniques and standard data that is either country specific or links countries to the source of the crisis." We argue that BIS statistics and CDS spreads do indeed contribute to our understanding of cross-border risks. A spillover mechanism is described in Kaminsky et al. (2003) who argue that a crisis of one country may spill into other countries in the presence of a "large common creditor" who in the face of losses in one country has to delever positions in other countries. This common creditor might be collections of other banks, financial institutions, or hedge funds.

Our empirical analysis supports the idea that the contingent liability (or implicit guarantee) that the sovereign may be assumed to give for the domestic banking system is a likely transmission mechanism - an issue discussed, for example, in Gray et al. (2007) and analyzed empirically in Ejsing and Lemke (2011). They find an increased sensitivity of sovereign debt to a global credit risk factor (proxied by an iTraxx index of non-financials) after the extension of bank guarantees in several European countries in the fall of 2008. Similar findings are presented in Alter and Schüler (2012). Dieckmann and Plank (2012) also demonstrate the effect on sovereign credit risk of the state of the domestic financial sector at the time of the onset of the crisis.

\section{The data}

The paper explains how sovereign default risk changes when the risk of the assets of the biggest banks in the country changes. We measure the default risk of the sovereign and of the banks through the CDS premia. Besides data on CDS premia, we need data on the riskiness of bank investments in the domestic and foreign markets, as well as controls regarding the local and global macroeconomic environment. Table A.3 contains an overview of the definition and data source behind all variables used in our regressions.

Our panel consists of 17 developed economies: Austria, Australia, Belgium, Switzerland, Germany, Denmark, Spain, France, United Kingdom, Greece, Ireland, Italy, Japan, the Netherlands, Portugal, Sweden, and the United States. ${ }^{3}$ We have obtained data for the period Q1:2004-Q4:2010 covering the most significant period of banking stress and ending before the onset of the ECB long-term refinancing operations in 2011 at which point collateralized borrowing in the central bank (see below) no longer can be used as an instrument for bank credit risk.

\subsection{CDS data}

We use 5-year sovereign CDS spreads, where the contracts are denominated in US dollar or Euro. Since not all the banks have traded CDS, we focus on explaining movements of CDS spreads of the largest banks. Table A.1 lists the largest banks. The bank CDS data are 5-year contracts, with senior unsecured debt as a reference obligation and denominated in the local currency.

We are also using bank and sovereign CDS data to construct a measure for the riskiness of exposures. The construction of the measure is explained in detail in Section 4. We obtain the CDS data from CMA which sources their information on executable and indicative prices directly from the largest and most active credit investors in the OTC market. We use end-of-quarter observations. Holes in the data, most notably in the early period, are filled using the Fitch CDS pricing source.

\subsection{Local bank variables}

When we explain the riskiness of bank investments, we need a proxy for domestic default risk. The proxy is the median of the expected default frequencies (EDF) from the local stock market data. The EDF provides an estimate of the default probability of a borrower. The estimate is obtained by using a structural model to back out firm asset value and asset volatility from observed equity prices and accounting information on leverage. From the estimated asset value and asset volatility, 'distance-to-default' (DD) is computed, and finally a non-parametric regression on historical data is used to find the empirical connection between DD and EDF, as explained in Crosbie and Bohn (2003).

Our extensive data set of EDFs covers all countries used in our exposure matrix calculations. For each country, we consider the median of the EDFs as the relevant risk measure. For our robustness checks, we have sorted the EDFs into the following categories: banks, other financials, real estate, and corporate, according to their SIC codes.

\subsection{Local government variables}

We have collected quarterly balance sheet data for the individual countries from IMF International Financial Statistics (IFS), OECD and Eurostat. The macro variables related to the sovereign risk we use are general government gross debt, long term external debt, the current account, net interest payments relative to revenue and changes in the estimated budget deficit. The latter variable is calculated as the sum of the most recent year-end and year-ahead budget projection by the OECD or the IMF minus

\footnotetext{
${ }^{3}$ We exclude Canada because we have no CDS data on Canadian sovereign debt, and we exclude BIS bank statistics reporting emerging markets because we have no CDS data for their banks.
} 
the second most recent forecast for the same period provided by the same organization. In quarters where they do not update a new budget projection, we interpolate a forecast.

We also take into account that the risk of a bank may be affected by the risk of the domestic sovereign through bank holdings of domestic sovereign debt. Since sovereign CDS spreads and bank CDS spreads are simultaneously determined, we follow Kallestrup (2011) and construct a measure which captures the part of sovereign risk, which is not related to the banking sector. We regress sovereign CDS premiums on a number of explanatory variables of sovereign credit risk. The explanatory variables include traditional fiscal variables such as gross or net general government debt (in domestic and foreign currency), short-term and long-term external debt and the government primary balance (i.e. total revenue less expenditure excluding gross interest payments) scaled against the domestic GDP. As macro-financial variables we include real GDP, the unemployment rate, the current account level and the net international investment position as percentage of GDP. Three variables significant in the regression of sovereign CDS premiums on the explanatory variables are government debt, long-term external debt, and the current account balance. The fitted value of the sovereign CDS spread from this regression, S_RISK, captures changes in sovereign credit risk arising from changes in fiscal fundamentals.

\subsection{Global variables}

We include a number of global variables that have been used in other works to explain movements in sovereign credit spreads, see for example Longstaff et al. (2011). The variables we use are the following:

- Excess return for the US stock market - computed as the difference between the value-weighted return on all NYSE, AMEX, and NASDAQ stocks (from CRSP) and the three-month treasury bill.

- Percentage changes in the 5 year constant maturity treasury yields.

- Percentage changes in the corporate yield spreads. The investment-grade yield spreads are computed on the basis-point yield spread between BBB and AAA industrial bond indices. The percentage changes in high-yield spreads are computed for the basis-point yield spread between $B B$ and $B B B$ industrial bond indexes. The used indices represent average yields of a broad cross-section of noncallable AAA-, BBB-, and BB-rated bonds with maturities approximately equal to 5 years.

- The volatility risk premium. This is computed as the difference between the VIX index and the realized volatility for the S\&P 500 index over the preceding 3 months.

- Percentage changes in the LIBOR-OIS spread which measures the difference between unsecured bank lending rates and comparable swap rates that have a very limited credit risk component.

- Itraxx SovX Western Europe comprising 15 names from the Eurozone region plus Denmark, Norway, Sweden and United Kingdom that trade on Western European documentation. All constituents are equally weighted and we use a computed theoretical price based on individual CDS premiums before the start of trading on 28 September 2009.

- The Markit iTraxx Non-Financials index comprising 100 equally-weighted European entities and the Markit iTraxx Senior Financials index which comprises 25 equally-weighted European entities. For both indices the underlying reference obligations are senior unsecured debt.

\section{The risk-weighted exposure matrix}

The key data describing the financial sector linkages are summarized in what we label as the BIS exposure matrix. We now describe how this is used together with CDS premiums to construct our risk measure for the major banks in each country. ${ }^{4}$

The consolidated banking statistics from BIS provide consolidated foreign claims of a national banking system in one country on all residents (i.e. public sector, banks and the non-bank private sector) of other countries. For example, the size of exposures of Austrian banks to residents of Hungary represents the aggregate claims of all Austrian-owned bank branches and subsidiaries around the world on all residents of Hungary, i.e. public sector, banks and the non-bank private sector. We have an aggregate exposure rather than the precise exposures of the Austrian banking system to each of these three categories. Other BIS statistics tell us that in Q4:2010, the total claims held by BIS reporting banks outside of Hungary were split among $10 \%$ claims on Hungarian banks, $30 \%$ claims on the Hungarian public sector and $60 \%$ claims on the non-bank private sector in Hungary. There is a very significant portion of non-bank private debt. The pattern is confirmed by the figures on all the countries in the world. In Q4:2010, the foreign claims of BIS reporting banks were split between approximately $23 \%$ claims on banks, $19 \%$ on the claims public sector and $58 \%$ claims on the non-bank private sector.

To construct our measure of riskiness of foreign exposures, we will use data for the size of the exposures and for the risk of the exposures. The data on the size of the exposures comes from BIS consolidated banking statistics. The riskiness of the exposures is

\footnotetext{
${ }^{4}$ We use BIS consolidated statistics with residency of the ultimate obligor when available. There are some holes in the data, most notable prior to 2005, which are filled with foreign exposures on an immediate risk basis. The ultimate obligor refers to the counterparty who is ultimately responsible for servicing any outstanding obligations in the event of a default by the immediate borrower. Suppose that an Austrian bank extends a loan to a company based in Hungary and the loan is guaranteed by a US bank. On an immediate borrower basis, the loan would be considered a claim of an Austrian bank on Hungary, as the immediate borrower resides in Hungary. On an ultimate risk basis, however, the loan would be regarded as a claim of an Austrian bank on the United States, since that is where the ultimate risk resides. We do not include foreign exposures via derivative markets, and guarantee extended and credit commitments as the data are not available for individual countries before December 2010. It is only for US banks that these other potential exposures account for a very large part of total foreign exposures. Our econometric results are robust to making pro-rate adjustments for these other potential exposures in foreign claims.
} 
measured by CDS premiums either on large banks or sovereigns. Exposures of each of the countries in our sample may well be to countries outside the sample. We need to have CDS data available for the banks or sovereigns for those other countries. Thus, countries that do not report to the BIS, like Korea and Iceland, are not in our sample of the 17 countries, but we are able to measure the riskiness of exposures to those two countries, since there are CDS data available for their largest banks.

We include foreign exposures of a country's banks until we have reached $85 \%$ of the total foreign exposure, as this eliminates the need to deal with countries for which a time series of CDS premiums is not available for the sovereign or the largest banks. To clarify exactly how our measure is constructed, consider the case of Austria. First, we list the countries to which the banks in Austria are exposed and order the countries by the size of the average exposure over the sample period. We then select enough countries so that the exposure in Q4:2010 is at least 85\% of the total exposure. This creates a list of countries to which the banks in Austria have the most significant exposures in that quarter, and we use this list throughout the sample period. Table 1 shows the 19 countries which account for at least $85 \%$ of the total foreign exposure. The remaining exposures are collected under 'others'. The table lists each aggregate foreign exposure, as it was reported in Q4:2010. For example, the exposure to Germany was USD 42.9 bn on average throughout the entire period and it was USD 48.2 bn in Q4:2010. The list is ordered according to the largest average exposure over the sample period. At the end of Q4 2010, the total foreign exposure of the Austrian banking system was USD 468.7 bn and the exposure to Germany accounted for roughly $10 \%$ of this.

We measure the riskiness of the foreign exposures by weighing each exposure with an appropriate CDS spread. If available, we use average bank CDS spreads for the two largest banks in the country of the exposure. The idea is that the riskiness of the private sector exposures in a given country is reflected in the CDS spreads of the largest banks in that country. At the end of Q4, the average CDS premium for the two largest banks in Germany was 126 bps. Since the exposure to Germany is 10\%, this means a risk-weighted value of $12.6 \mathrm{bp}$. When bank CDS spreads are not available for the risk weighting of exposures, as is typically the case for emerging markets, we use the sovereign CDS spreads instead. In emerging markets, a large part of the riskiness of an exposure is related to political and currency risk, risks that are also reflected in the sovereign CDS spreads. Empirical results in Dittmar and Yuan (2008) confirm the strong correlation between corporate credit spreads and sovereign credit spreads in emerging markets. The risk-weighted sum of CDS spreads for all countries to which Austria is exposed is 163 basis points. The weights of the countries in the exposure matrix only sum to 0.86 . Hence the weighted average CDS spread of the exposures that enter the sample is $1 / 0.86 \times 163 \mathrm{bps}=190 \mathrm{bps}$. Note that this measure is a risk-weighted average of Austrian banks' exposure to other countries in Q4:2010.

The measure changes through time as the weights of the exposures shift between countries and as the CDS spreads for the countries change. The risk-weighted foreign exposure is only expected to matter if the size of the exposure is large enough relative to other exposures. As shown in Table 2 the total exposure of the Austrian banking system is USD 1010 bn, i.e. the foreign exposures account for almost half of the total exposure.

Table A.2 shows summary statistics on foreign exposures for each of the 17 countries. The table shows the relative size and the (foreign) country of the largest exposure. It also shows the standard deviation of the time-series variation in the relative size of the largest exposure. This standard deviation ranges from 0.02 to 0.1 . While this does show some time-series variation in

Table 1

The foreign exposure matrix: Austria. The table shows the exposures to the countries toward which the Austrian banking system has its 19 largest exposures until $85 \%$ of the exposures are accounted for. There is no liquid historical CDS spread on Serbia (RS) and we thus use the one on Croatia (HR).

\begin{tabular}{|c|c|c|c|c|c|c|c|c|}
\hline Rank & Country & Average (USD bn) & Q42010 (USD bn) & Share & Acc & Spread & Type & Share $\times$ CDS \\
\hline 1 & $\mathrm{DE}$ & 42.9 & 48.2 & 0.10 & 0.10 & 126 & Bank & 13 \\
\hline 2 & $\mathrm{CZ}$ & 34.8 & 59.6 & 0.13 & 0.23 & 91 & Sov & 12 \\
\hline 3 & $\mathrm{HU}$ & 23.2 & 35.0 & 0.07 & 0.34 & 378 & Sov & 28 \\
\hline 4 & RO & 23.1 & 39.5 & 0.08 & 0.42 & 297 & Sov & 25 \\
\hline 5 & GB & 21.6 & 15.8 & 0.03 & 0.26 & 169 & Bank & 6 \\
\hline 6 & HR & 19.5 & 31.3 & 0.07 & 0.49 & 256 & Sov & 17 \\
\hline 7 & SK & 18.8 & 27.9 & 0.06 & 0.55 & 82 & Sov & 5 \\
\hline 8 & US & 17.4 & 16.3 & 0.03 & 0.58 & 132 & Bank & 5 \\
\hline 9 & IT & 17.1 & 22.2 & 0.05 & 0.63 & 176 & Bank & 8 \\
\hline 10 & RU & 11.0 & 15.2 & 0.03 & 0.66 & 147 & Sov & 5 \\
\hline 11 & $\mathrm{NE}$ & 10.8 & 15.7 & 0.03 & 0.70 & 113 & Bank & 4 \\
\hline 12 & PL & 9.6 & 14.3 & 0.03 & 0.73 & 144 & Sov & 4 \\
\hline 13 & SI & 8.4 & 15.4 & 0.03 & 0.80 & 77 & Sov & 3 \\
\hline 14 & FR & 8.3 & 9.3 & 0.02 & 0.75 & 142 & Bank & 3 \\
\hline 15 & RS & 7.7 & 7.0 & 0.01 & 0.76 & 256 & Sov & 4 \\
\hline 16 & $\mathrm{CH}$ & 7.7 & 11.2 & 0.02 & 0.82 & 100 & Bank & 2 \\
\hline 17 & UA & 6.1 & 8.8 & 0.02 & 0.84 & 510 & Sov & 10 \\
\hline 18 & IE & 6.0 & 2.9 & 0.01 & 0.83 & 1052 & Bank & 6 \\
\hline 19 & ES & 5.5 & 6.7 & 0.01 & 0.86 & 259 & Bank & 4 \\
\hline- & Others & - & 66.3 & 0.14 & 1.00 & - & - & - \\
\hline- & Total & - & 468.7 & 1.00 & 1.00 & - & - & 163 \\
\hline
\end{tabular}


Table 2

The total exposure: Austria. The table shows the composition of assets for Austrian banks. The claims on the domestic sovereign include the domestic general government and the central bank. Assets are reported both in nominal value and as percent of GDP.

\begin{tabular}{lrc}
\hline Claims on & USD bn & \% GDP \\
\hline Non-nationals & 468.7 & 124 \\
Domestic sovereign & 77.7 & 20 \\
Other domestic residents & 464.0 & 0.46 \\
Total & 1010.4 & 0.08 \\
\hline
\end{tabular}

exposures, a much larger source of variation in our exposure measures comes from the huge fluctuations in CDS premia. In addition, there is great geographical variation in the countries to which different banks are exposed.

The 5-year CDS spread for Austria depicted in Fig. 1 shows a clear covariation with the exposure measure. Our hypothesis is that this covariation does not merely reflect common variation in all CDS spreads, but is rooted in economic fundamentals.

\section{Bank foreign exposures and bank CDS dynamics}

Our first task is to investigate whether movement in our risk-weighted exposure measure is capable of explaining movements in bank CDS spreads. Specifically, we analyze whether changes in the average of the CDS spreads of the two largest banks in a country can be explained by a change in the relative size and the riskiness of foreign exposures as captured by our risk measure.

We start by running the following panel regression:

$$
\begin{aligned}
\Delta\left(\text { B_CDS }_{k_{k, t}=}=\right. & \alpha_{k, 0}+\alpha_{1} \times \Delta\left({\text { B_BIS_CDS })_{k, t}}\right. \\
& +\alpha_{2}^{\prime} \times \Delta(\text { Local Bank Variables })_{k, t} \\
& +\alpha_{3}^{\prime} \times \Delta(\text { Global Variables })_{t} \\
& +\alpha_{4}^{\prime} \times \Delta(\text { CDS Indices })_{t}+\varepsilon_{k, t}
\end{aligned}
$$

Here, $\Delta\left(B_{-} C D S\right)_{k, t}$ denotes the change from quarter $t-1$ to $t$ in average bank CDS spreads for country $k$. We follow this notation throughout, so that $\Delta$ (B_BIS_CDS $)_{k, t}$ denotes the change in the exposure weighted credit spread for country $k$ from quarter $t-1$ to $t$. The measure is constructed exactly as explained for the case of Austria in Section 4. Local bank variables are EDF measures for different sectors. They control for the risk of domestic borrowers. To motivate our focus on EDFs, it is useful to consider the case of Spain. Spain's

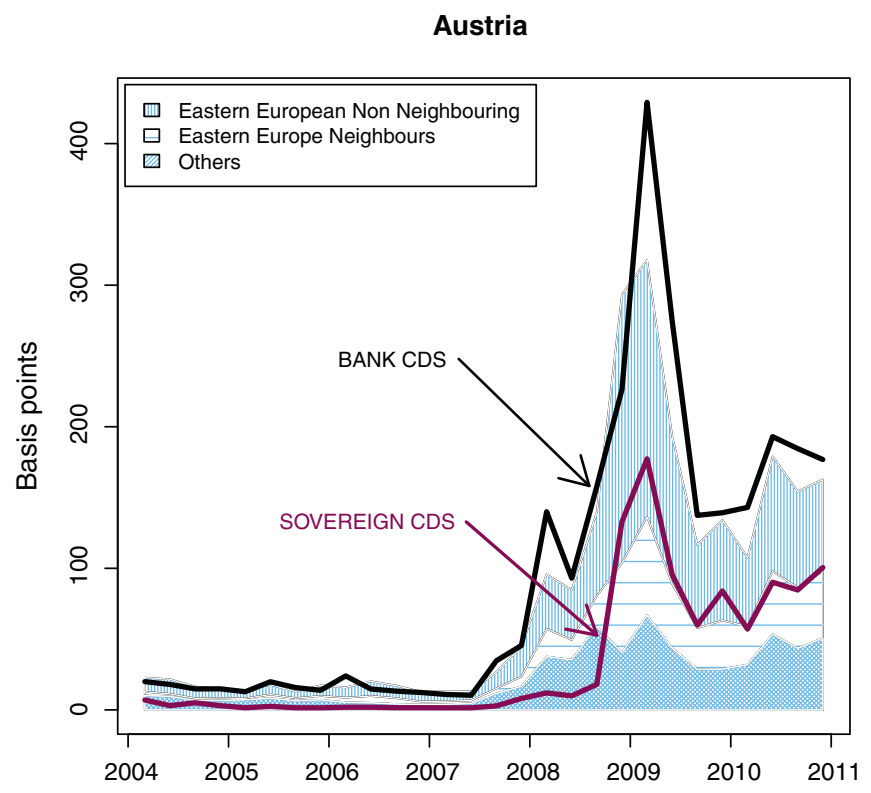

Fig. 1. Austria dynamic exposure. The graph shows the average CDS spread for the two largest banks compared with the sovereign CDS spread. In the background we have the exposure measure decomposed into major geographical regions: Eastern Europe non-neighboring countries; Eastern Europe neighboring countries (Czech Republic, Hungary, Slovakia and Slovenia); other countries. 


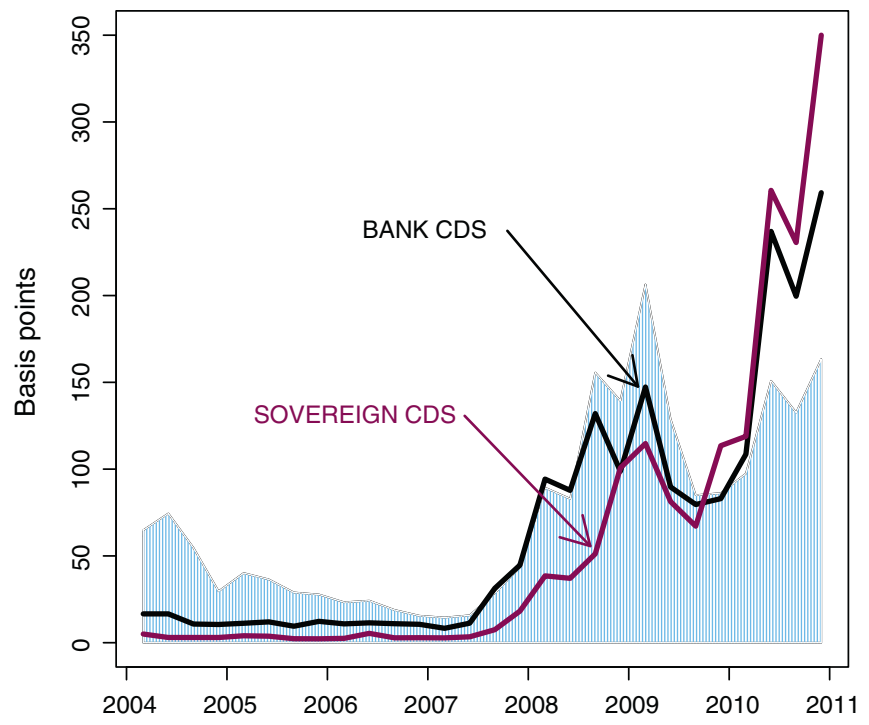

Fig. 2. Spain's dynamic exposure. The graph shows the average CDS spread for the two largest banks compared with the sovereign CDS. In the background we have the exposure measure for Spain.

BIS matrix exposure does not seem to explain all the movement of Spain's average bank CDS spread throughout the entire period. As seen in Fig. 2, there is an increase in CDS premiums for the largest Spanish banks in 2010 that is not explained entirely by the risk of their foreign exposures. To measure the banks' risk from their exposure to domestic loans, we will use expected default frequency (EDF) measures as proxies for this risk. Fig. 3 shows the dynamics of median firm EDFs in three sectors for Spain and Austria: banking, non-financial corporates and for the real estate sector. While the EDFs for both the corporate sector and the real estate sectors increase for Austria, they are at a higher level over the last 2 years of the sample in Spain, which sees a very large spike in the real estate EDFs and also a higher level of corporate EDFs than Austria. The spike in bank EDFs in Spain is very large and in combination, Figs. 1-3 suggest that the spike in CDS spreads of Spanish banks was much more driven by domestic factors and Austria's spike was much more driven by foreign exposures.

In Austria, there is a high co-movement between the CDS spread for banks and the Austrian banks' foreign exposureweighted CDS spreads. It indicates that Austrian banks were hit by a shock originating abroad, especially in Eastern Europe. On the contrary, in Spain we see a low co-movement, indicating that the credit risk primarily originated in the domestic economy.

Global variables are a vector of variables listed in Section 3.4. Finally, since our exposure measure uses information from CDS markets, we need to control for general movements in CDS spreads. We do it by including three general European CDS indices: The iTraxx Sovereign Western Europe, iTraxx Senior Financials and iTraxx Non-Financials. They are used in the regression directly, and in a two-step procedure. In the two-step procedure, we regress our exposure measure on the three indices and then we use the residual as explanatory variable. The idea is to extract the part of our exposure measure, which is not captured by common CDS movements. The regression uses ordinary least squares (OLS) with robust standard errors and fixed effects. The result is reported in Table B.1. Column I of this table presents the result of the regression without the CDS indices to emphasize the important role of controlling for common movements in the CDS markets.

The exposure-weighted credit spread is highly significant both when we control with the indices directly (column II) and when we use the residuals (column III). In the regression which includes the indices as controls directly, a 100 basis point increase in the exposure-weighted credit spread corresponds to a 52 basis point increase in the average bank CDS spreads. Interestingly, we cannot show that this effect is significantly weaker in the period leading up to the crisis, even if the regression coefficient (column IV) is estimated to be smaller in the first part of the sample. The real estate EDF measure, R2_EDF, which measures median default probabilities in the real estate sector (broadly defined), is also highly significant in all regressions, which is consistent with the important role played by real estate in bank losses during the financial crisis. In contrast, except for S_RISK and the iTraxx index for senior financials, none of the other local or global variables are significant even at the 5\% level in the full sample. Surprisingly, the more general corporate EDF measure for the entire corporate sector, C2_EDF is not significant. This could be due to strong correlation with real estate EDFs. When we regress bank CDS premiums on the EDF measure for the entire corporate sector, it is highly significant.

One could argue that there are "second order effects" of foreign exposures in the following sense: German banks, for example, have foreign exposures to Spain whose banks in turn have foreign exposures in Mexico. Should this count as a German exposure to Mexico? Our numbers show that this effect is extremely small and can be ignored. For example, German banks have $44 \%$ of 
Austria
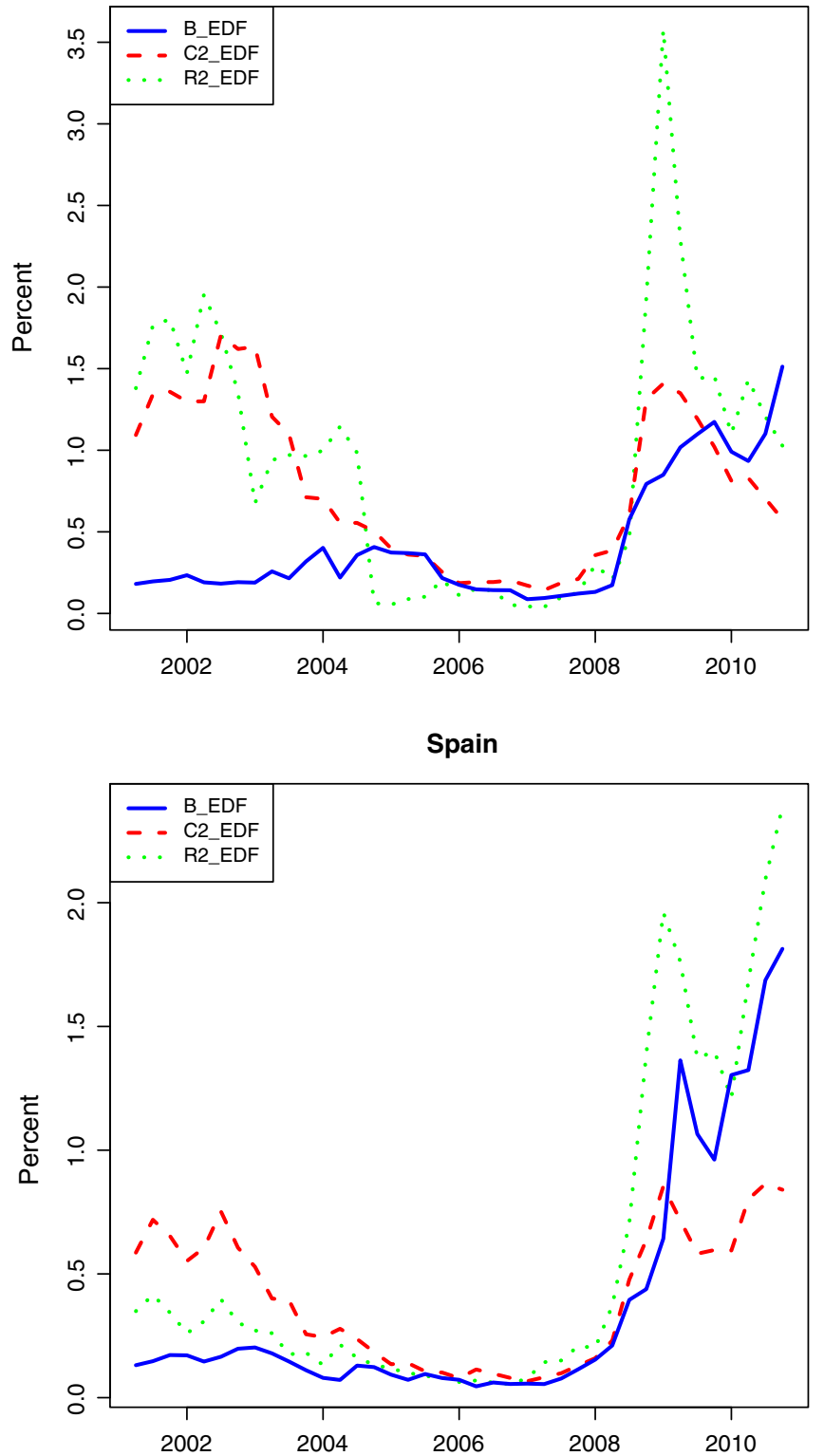

Fig. 3. Bank, corporate and real estate EDFs for Austria and Spain. Austrian banks exposed to some increase in real estate and corporate risk, but the order of magnitude is far from that of Spain. Green: Real estate 5-year EDFs; Blueish: Bank 5-year EDFs; Red: Non-bank corporate 5-year EDFs.

their assets as foreign exposures. 6\% of those exposures are to Spanish sovereign debt, Spanish banks and private borrowers. Spanish banks have $28 \%$ of their assets in foreign assets, and of those $10 \%$ are to Mexico. In the extreme case that all German banks' foreign exposures were to Spanish banks, the total exposure to Mexico would be $0.07 \%$ of German bank assets. The actual number is of course significantly smaller, since a large part of German bank exposures to Spain is to the Spanish government and private borrowers with no exposure to Mexico.

In a similar vein, one could worry about feedback loops. A strong candidate for such worries would be the case of the UK and the USA. UK banks have $27 \%$ of their foreign exposures to the USA. Foreign exposures of US banks account for $10 \%$ of their assets, and of those foreign exposures, $19 \%$ are to the UK. Thus, in the extreme case, where all UK foreign exposures to the USA were exposures to banks, and all foreign exposures of US banks to the UK were to UK banks, the 'feedback' exposure of UK banks to themselves would only account for $0.5 \%$ of foreign exposures, or $0.25 \%$ of total assets. The true number is likely to be much smaller, because a large part of UK banks' exposures to the USA are to non-bank entities (private borrowers and US government 
securities). The same argument argument applies to US exposures, and this justifies looking only at the direct exposures in our BIS matrix.

\subsection{Robustness checks}

We perform several robustness checks to firmly establish that the cross-border exposures of banks are significant in explaining the dynamics of bank CDS spreads.

First, we replace all global factors by a time fixed effect and run a regression on the country specific explanatory variables that include EDF measures and measures of domestic sovereign risk. The time fixed effects are included as we may still have left out an important factor which jointly determines the level of CDS spreads across banks. The results are reported in Table B.2. Our measure of financial exposures is still significant over the full sample and in the subsample that begins with the onset of the financial crisis. Similarly, the country-specific EDFs and the sovereign risk measure are both significant throughout the sample as well as in the second period, although the real estate EDF is weakly significant in the period before the crisis as well.

Second, it is possible that the results are driven by a few countries in our panel which have a large fraction of their assets in foreign exposures. We divide the sample in two parts according to the average size of foreign exposures (relative to total assets) over the sample period. In the sample of countries whose banks have high foreign exposures compared to assets, the lowest average exposure is that of Great Britain with $42 \%$ and the highest is that of Switzerland with $71 \%$. In the sample with low foreign exposures compared to assets, the highest is that of Spain with an average of $28 \%$ and the lowest is that of the USA with $11 \%$. As seen in Table B.3, we find that in both subsamples our dynamic exposure measure is significant in explaining the dynamics of bank CDS spreads. We also leave out the USA from the sample because of the potential special status of the US economy in affecting global CDS spreads. Excluding the USA does not change our results, as seen in the last column of Table B.3.

Third, even when we divide in subsamples of countries with high and low foreign exposure, the range covered in each group is quite high. More generally, the distribution of bank assets on domestic sovereign, domestic private and foreign exposures varies considerably across countries. We therefore define

$$
\begin{aligned}
& \text { B1 }=\frac{\text { Foreign claims }}{\text { Bank assets }} \\
& \text { B2 }=\frac{\text { Domestic credit }}{\text { Bank assets }} \\
& \text { B3 }=\frac{\text { Claims on sovereign }}{\text { Bank assets }}
\end{aligned}
$$

and use B1 $\times \Delta(\text { B_BIS_CDS })_{k, t}, \mathrm{~B} 2 \times \Delta\left(\mathrm{EDF} \_\mathrm{ALL}\right)_{k, t}$, and B3 $\times \Delta\left(\mathrm{S} \_\mathrm{RISK}\right)_{k, t}$ as regressors. We report the results in Table B.4. Note that the coefficient on B1 $\times \Delta$ (B_BIS_CDS $)_{k, t}$ is now 1.22 , but since B1 is on average 0.379 , the effect of changes in the exposure matrix is the same as before. The advantage of the weighting scheme is that it allows us to differentiate the impact of changes in the exposure measure between countries with different exposures. For example, a 1 basis point increase in our foreign exposure measure translates into a 0.88 bp increase for Switzerland, and a $0.13 \mathrm{bp}$ increase for the USA. Also, we note that the effect of foreign exposures clearly dominates the effect of both types of domestic exposures. Specifically, a 1 standard deviation change in B_BIS_CDS on average translates into a 29 bp change in bank CDS premia, a 1 standard deviation change in S_RISK on average translates into a 9 bp change in bank CDS premia, and a 1 standard deviation change in EDF_ALL on average translates into an 8 bp change in bank CDS premia. Consistent with the new emphasis on bank holdings of sovereign risk in the recent crisis, domestic sovereign risk is only significant in the second part of our sample.

Fourth, in Table B.5 we test the relevance of the information in the BIS exposure matrix by running a regression in which we leave out the five largest foreign exposures when we calculate the exposure measure for each country's banking system. This new exposure measure is not able to explain variations in bank CDS spreads once we control with the CDS indices. This jointly illustrates the importance of controlling for general movements in CDS markets and the significance of our exposure measure. When we remove the five biggest exposures, the exposure measure is significant before controlling for the CDS indices, but it loses significance with the introduction of the indices. It is in contrast with our full exposure measure which remains significant even after including the indices. Thus, our exposure measure contains information that is reflected in CDS premiums and which is not due to movements in indices or other global variables. Note that it is not the case that the GIIPS countries are consistently among the top five exposures. In fact, only five countries (France, Germany, UK, Portugal and Spain) in our sample have their most important exposures to GIIPS countries. Also note that when running this placebo test, we rescale the exposure measures so that the coefficients on our measure and the placebo measure become comparable. The problem is that when we leave out the five biggest exposures, the exposure measure becomes smaller simply because we have removed a weighted sum of five CDS spreads. Thus, if our exposure measure is based on 
$85 \%$ of bank exposures and the adjusted measure only takes into account $30 \%$ of the exposures, we rescale the first measure by dividing by 0.85 and the second measure by 0.3 .

Last, in Table B.6 we perform a few additional robustness tests. We show that using equal weights on the exposures instead of weighing by exposure size also gives a significant exposure measure. Thus the most important part of our exposure measure is selecting the countries to which a banking system is exposed. We choose to work with the actual weights as this is less ad hoc than using equal weights. In unreported tests, we checked that a concentration measure (such as a Herfindahl index) does not help us explain the variations in bank CDS spreads. This confirms that the detailed composition of the weights is less important than accounting for the largest exposures. We also run a regression in which we use sovereign CDS premiums to measure the riskiness of exposures in all countries - and not just those for which we have limited or no information on bank CDS spreads. The results are reported in columns IV-VI in Table B.6. Again the significance of the exposure measure is not affected.

\section{Sovereign CDS spreads and contingent liabilities}

So far we have considered the asset side of the banks' balance sheets focusing on measures of asset quality that include financial linkages, and we have shown that they can help explain bank risk as measured by CDS premia. Implicit and explicit government guarantees imply that bank risk plays a huge role on the liability side of sovereign's balance sheet. In this section, we show that bank risk is a significant factor in the determination of sovereign credit spreads. The regression now has the following form:

$$
\begin{aligned}
\Delta\left(\mathrm{S}_{-} \mathrm{CDS}\right)_{k, t}= & \alpha_{k, 0}+\alpha_{1}^{\prime} \times \Delta(\text { Domestic Government Variables })_{k, t} \\
& +\alpha_{2}^{\prime} \times(\text { Guarantees })_{k, t} \\
& +\alpha_{3}^{\prime} \times \Delta(\text { Global Variables })_{t}+\varepsilon_{k, t}
\end{aligned}
$$

where global variables and domestic government variables are defined above. The fiscal variables are traditionally viewed as determinants of sovereign default risk. The term "guarantees" refers to variables seeking to measure the size and riskiness of implicit and explicit guarantees made to the domestic banking system. The explicit guarantee (labeled guarantees in Table B.7) is a variable which is only active (i.e. non-zero) in quarters where a country has issued an explicit guarantee on parts of banks' liabilities, i.e. the dummy is active in the quarter in which the guarantee is issued and zero otherwise. ${ }^{5}$ When this is the case, the variable takes on a value equal to the size of the guarantee relative to GDP, as reported by IMF (2009). For all countries, this guarantee is made in Q4:2008. ${ }^{6}$

We have two additional variables seeking to measure the size of the sovereign's 'contingent liability' on the banking sector. The first variable is the size of the domestic banking system (measured as claims on domestic entities and nonnationals) relative to GDP multiplied by the average CDS premium of the two largest banks. This measure combines the size of the potential liability and its riskiness into one measure. The second variable uses median bank EDF instead of bank CDS to measure riskiness.

Columns I and II of Table B.7 report the result of the regression when we use the CDS-based measure for the size of the implicit guarantee. Column I does not include the Q4:2008 explicit guarantees, whereas column II does. Both implicit and explicit guarantees are highly significant. In columns III and IV the riskiness of implicit guarantees is measured using EDFs. Again, both implicit and explicit guarantees are highly significant. In all four regressions, the excess return on the US equity market, and changes in yield spreads on investment grade and high yield bonds are not significant which is in contrast to the findings in Longstaff et al. (2011). This may be because we include CDS indices as our explanatory variables.

Column V addresses the possibility of endogeneity of bank CDS premia, i.e. that sovereign and bank CDS are determined jointly. To demonstrate that bank CDS premiums do indeed influence sovereign CDS premia, we choose as an instrument for bank credit risk the amount of short-term central bank funding of banks - typically done through collateralized lending. The idea is that increases in central bank funding are a sign of increased bank credit risk, but unrelated to sovereign risk through any other channel. It is conceivable that the increase in central bank funding was part of a plan to support bank purchases of sovereign debt and hence the increase in bank funding was spurred by sovereign risk. We follow Kallestrup (2011) and include a Granger causality test to check the direction of causality. We find evidence that changes in central bank funding Granger cause bank and sovereign CDS spreads (with t-statistics of 2.43 and 1.693 respectively), but we find no evidence that sovereign or bank CDS spreads Granger cause central bank funding (t-statistics of 0.09 and 1.3 respectively). This supports our use of central bank funding as an instrument for bank credit risk. It should be noted that the 3-year LTRO programs introduced by the ECB at the end of 2011 and in 2012, which for example lead to Italian and Spanish banks increasing their exposure to the domestic sovereign are not in our sample period. See Acharya and Steffen (2015) for more on this.

\footnotetext{
5 There have been many types of financial support schemes, such as capital injections, purchases of assets, central bank support and liquidity provisions. These are not included here.

${ }^{6}$ The guarantee on the Irish banking system was given in September 29 and in force in September 30. The price impact seems to mostly take place in Q4, and therefore we have used this as the relevant quarter for Ireland also.
} 
With this instrument, we find that the current long-term government liabilities are significant. The negative sign on the LIBOR-OIS spread is somewhat puzzling. An increase in this variable should indicate an increase in general bank credit risk and we would therefore expect a positive sign of the regression coefficient. The reason may be that the LIBOR-OIS spread and the yield spreads of corporate bonds are correlated. Unsurprisingly, the general level of sovereign credit risk as measured by iTraxx sovereign index is significant.

Was the importance of implicit guarantees already priced in the sovereign CDS market before the crisis? To investigate this question, we have split our sample into two sub-periods and find the results reported in Table B.8. Before the crisis, the sovereign CDS spreads are not influenced by the implicit guarantees as measured through the size and riskiness of the domestic banking system. This result is confirmed in the last three columns of Table B.8 where we used a general time-fixed effect instead of the CDS indices to control for common, global factors in CDS spreads.

As a robustness test, we rerun all regressions pertaining to sovereign risk using the average leverage of the two largest banks, as an instrument for bank risk. The results are presented in Table B.9. They are robust and consistent with those obtained from using short-term central bank funding of banks. Bank leverage ratios are shown by Demirguc-Kunt et al. (2013) to be a stronger predictor of bank equity returns during the crisis than measures of capitalization using risk-weighted assets. Higher leverage is associated with a higher risk of poor bank performance, and this risk is likely a consequence of a higher risk level chosen by the bank and not related to the state of the sovereign. We view the use of leverage as instrument mainly as a robustness check since statistical tests show that it is a weak instrument. The F-statistic of the first stage regressions is much higher for the short-term central bank funding of banks than for bank leverage.

At this point, we have strong evidence that bank CDS spreads are affected by foreign exposures of banks and that the risk of banks in turn spills over to sovereign CDS spreads. This provides a strong case for arguing, that the evolution of sovereign CDS spreads is affected by the foreign exposures of domestic banking systems, thus establishing a concrete and measurable source of covariation between sovereign spreads.

Our final goal is to examine whether this effect materializes itself in a direct regression of sovereign CDS spreads on measures for the riskiness of banking fundamentals, EDFs and our BIS exposure measure. Table B.10 shows that sovereign CDS spreads are affected by the risk of bank exposures as measured through our BIS measure and through EDFs. This is true whether we control for global variables and CDS indices (column I) or use time-fixed effects (column II). An increase of 1 standard deviation in the BIS exposure measure leads to an increase of 24 basis points in the sovereign CDS spreads, i.e. about one quarter of the standard deviation. An increase of 1 standard deviation in the median EDF leads to an increase of 40 basis points in the sovereign CDS spreads. Longstaff et al. (2011) found that the performance of the national stock market is not very important in explaining movements in the sovereign CDS spreads. Our findings suggest that the influence on sovereign CDS premiums from the domestic economy is better captured through the risk of the banking sector. This is consistent with the fact that all countries in our sample have a very large banking sector compared to their GDP. Indeed, the size of the domestic banking system (measured as claims on domestic entities and non-nationals) relative to GDP has a median of $259 \%$ of the GDP. The minimum is $93 \%$ for USA in 2004 and the maximum is $800 \%$ of the GDP for Switzerland in 2008. The significance of EDFs and of our BIS measure shows that the riskiness of the local banking systems has both a domestic and a foreign component. The influence on sovereign CDS premiums of the foreign exposures of banks is clear evidence that bank risk affects sovereign risk irrespective of any feedback loops that may arise due to bank holdings of domestic sovereign bonds.

\section{Conclusion}

We use BIS consolidated banking statistics to construct a simple risk-weighted measure of foreign exposures of banking systems in 17 countries. Our measure captures in a simple way how the foreign asset holdings of the largest banks are an important determinant not only of their own CDS premiums, but also of the CDS premium of the sovereign in which the banks reside. Extensive robustness checks confirm that the significance of our measure cannot be attributed to common variation in CDS spreads.

It is to be expected that the riskiness of a bank's assets affects the CDS premium of the bank, but the degree to which the CDS market captures this is remarkable and it is conceivable that risk management practice and banking regulation are also playing a role. A common practice among hedge funds and risk managers is to hedge exposures through 'proxy hedging' - i.e. hedging through correlated but 'cheaper' hedging vehicles (see e.g. IMF, 2010 and Association for Financial Markets in Europe, 2011). For example, a bank may wish to hedge emerging market credit risk in Eastern Europe, either because it has exposure to sovereigns itself (as a direct exposure or as counterparty risk in large derivative contracts) or because it wishes to hedge a large loan exposure in such countries using a 'macro' hedge. Buying protection on Austrian banks which are known to have large exposures in these countries may provide a cheaper hedge. Similarly, an exposure to a major bank can be a 'proxy' hedged using a CDS on the sovereign in which the bank resides. Furthermore, in the latter part of our sample period, Basel III rules begin to encourage banks to use CDS contracts to hedge changes in credit value adjustments (CVA), i.e. adjustments in the value of derivative positions due to counterparty credit risk. The hedge can be done either through a CDS contract referencing the specific counterparty or through a proxy hedge on a sovereign when the CDS is not available. Our findings are consistent with the hypothesis that CDS premiums reflect the value of CDS contracts in providing capital relief for financial institutions, see for example Yorulmazer (2012) and Klingler and Lando (2015).

In light of the statistics made public by the European Banking Association after its 2010 stress tests of European banks which document the dominant role played by private foreign exposures, our findings support the recent recommendation in the October 
2013 IMF Global Financial Stability Report, which“the ECB's upcoming bank balance sheet assessment should, among other things, focus on corporate exposures”, see IMF (2013).

\section{Appendix A. Summary statistics and variable description}

\section{Table A.1}

Banking groups as percentage of GDP, 2009. The table lists the largest banks in each country used to find the average bank CDS spread.

\begin{tabular}{|c|c|c|c|c|}
\hline \multirow[b]{2}{*}{ Country } & \multirow[b]{2}{*}{ Bank name } & \multirow{2}{*}{$\frac{\text { Size of bank }}{\text { USD bn }}$} & \multirow{2}{*}{$\frac{\text { GDP }}{\text { USD bn }}$} & \multirow[b]{2}{*}{$\%$ GDP } \\
\hline & & & & \\
\hline AT & Erste Group Bank AG & 291 & 382 & 76 \\
\hline AT & Raiffeisen Zentralbank Oesterreich AG & 213 & 382 & 56 \\
\hline AU & National Australian Bank & 576 & 994 & 58 \\
\hline AU & Westpac & 519 & 994 & 52 \\
\hline $\mathrm{BE}$ & Dexia Group NV & 832 & 472 & 176 \\
\hline $\mathrm{BE}$ & KBC Group NV & 467 & 472 & 99 \\
\hline $\mathrm{CH}$ & UBS AG & 1301 & 492 & 264 \\
\hline $\mathrm{CH}$ & Credit Suisse Group AG & 1001 & 492 & 203 \\
\hline $\mathrm{DE}$ & Deutsche Bank AG & 2162 & 3339 & 65 \\
\hline $\mathrm{DE}$ & Commerzbank AG & 1216 & 3339 & 36 \\
\hline DK & Danske Bank AS & 597 & 310 & 193 \\
\hline ES & Banco Santander SA & 1600 & 1468 & 109 \\
\hline ES & Banco Bilbao Vizcaya Argentaria SA & 771 & 1468 & 53 \\
\hline FR & BNP Paribas & 2964 & 2656 & 112 \\
\hline FR & Crédit Agricole-Crédit Agricole Group & 2440 & 2656 & 92 \\
\hline GB & Royal Bank of Scotland Plc & 2749 & 2179 & 126 \\
\hline GB & Barclays Bank Plc & 2234 & 2179 & 103 \\
\hline GR & National Bank of Greece SA & 163 & 331 & 49 \\
\hline GR & EFG Eurobank Ergasias SA & 121 & 331 & 37 \\
\hline IE & Bank of Ireland Plc & 261 & 222 & 117 \\
\hline IE & Allied Irish Banks Plc & 251 & 222 & 113 \\
\hline IT & Unicredit SpA & 1338 & 2118 & 63 \\
\hline IT & Intesa Sanpaolo SpA & 900 & 2118 & 42 \\
\hline JP & Mitsubishi UFJ Financial Group & 1930 & 5069 & 38 \\
\hline $\mathrm{JP}$ & Sumitomo Mitsui Financial Group & 1144 & 5069 & 23 \\
\hline $\mathrm{NE}$ & ING Group NV & 1676 & 797 & 210 \\
\hline $\mathrm{NE}$ & Rabobank & 875 & 797 & 110 \\
\hline PT & Banco Comercial Portugues SA & 138 & 233 & 59 \\
\hline PT & Banco Espirito Santo SA & 119 & 233 & 51 \\
\hline SE & Nordea Bank AB & 731 & 406 & 180 \\
\hline SE & Skandinaviska Enskilda Banken AB & 324 & 406 & 80 \\
\hline US & Bank of America Corporation & 2223 & 14,119 & 16 \\
\hline US & JP Morgan Chase Co. & 2032 & 14,119 & 14 \\
\hline
\end{tabular}

Table A.2

Summary statistics: foreign exposures. The table shows the relative size and the country of the largest exposure. It also displays the time-series variation in the relative size of the largest exposure. Source: Bank for International Settlements and own calculations. Exposure data for Ireland exists from 2006 to 2010.

\begin{tabular}{|c|c|c|c|c|c|}
\hline Country & $\begin{array}{l}\text { Share of exposure explained } \\
\text { in Q4 } 2010\end{array}$ & Countries included & Maximum exposure & $\begin{array}{l}\text { Country with maximum } \\
\text { exposure }\end{array}$ & $\begin{array}{l}\text { Standard deviation } \\
\text { of maximum exposure }\end{array}$ \\
\hline AT & 0.86 & 19 & 0.16 & $\mathrm{DE}$ & 0.02 \\
\hline AU & 0.87 & 9 & 0.49 & $\mathrm{NZ}$ & 0.02 \\
\hline $\mathrm{BE}$ & 0.87 & 13 & 0.63 & $\mathrm{NE}$ & 0.02 \\
\hline $\mathrm{CH}$ & 0.85 & 17 & 0.51 & US & 0.04 \\
\hline $\mathrm{DE}$ & 0.85 & 32 & 0.24 & GB & 0.03 \\
\hline DK & 0.86 & 7 & 0.29 & GB & 0.02 \\
\hline ES & 0.86 & 9 & 0.36 & GB & 0.04 \\
\hline FR & 0.86 & 25 & 0.27 & US & 0.03 \\
\hline GB & 0.86 & 20 & 0.36 & US & 0.03 \\
\hline GR & 0.85 & 13 & 0.31 & TR & 0.05 \\
\hline IE & 0.85 & 9 & 0.39 & GB & 0.03 \\
\hline IT & 0.85 & 19 & 0.35 & $\mathrm{DE}$ & 0.10 \\
\hline JP & 0.86 & 16 & 0.47 & US & 0.02 \\
\hline $\mathrm{NE}$ & 0.88 & 13 & 0.28 & US & 0.04 \\
\hline PT & 0.86 & 16 & 0.21 & ES & 0.02 \\
\hline SE & 0.85 & 9 & 0.28 & DK & 0.04 \\
\hline US & 0.85 & 19 & 0.23 & GB & 0.03 \\
\hline
\end{tabular}


Table A.3

Variable description.

\begin{tabular}{|c|c|c|}
\hline Variable & Description & Source \\
\hline B_GDP & $\begin{array}{l}\text { Aggregates data regarding: } \\
\text { - banks' claims on domestic central bank (percent of GDP); } \\
\text { - banks' claims on domestic general government (percent of GDP); } \\
\text { - banks' claims on other sectors in the country (percent of GDP); } \\
\text { - banks' claims on non-nationals (percent of GDP) }\end{array}$ & IFS \& BIS \\
\hline B_CREDIT & Banks' claims on other sectors in the country. Percent of GDP & IFS \\
\hline B_EDF & Median of the 5-year EDFs for the banking sector & Moody's KMV \\
\hline B_FExp & Banks' claims on non-nationals. Percent of GDP & BIS \\
\hline B_CB_L & Banks' liabilities to the domestic central bank. Percent of GDP & IFSand the Bank of England \\
\hline Leverage & Average of the banks' leverage. It is computed as total regulatory capital/total assets. & Bankscope \& IFS \\
\hline B_CDS & Average of 5-year CDS on domestic banks & CMA and Fitch CDS Pricing \\
\hline B_BIS_CDS & Exposure-weighted credit spread computed using both sovereign and bank CDS data. See the main text & BIS \\
\hline B_BIS_RES & A fitted value from a regression of B_BIS_CDS on the CDS indices B_FINSNR, F_NONFIN, and S_SOVX & Own calculations \\
\hline B_BIS_NOT5 & $\begin{array}{l}\text { Exposure-weighted credit spread computed using both sovereign and bank CDS data, but leaving out the } \\
\text { largest } 5 \text { exposures. See the main text. }\end{array}$ & BIS \\
\hline BIS_NOT5_RES & A fitted value from a regression of B_BIS_NOT5 on the CDS indices B_FINSNR, F_NONFIN, and S_SOVX & Own calculations \\
\hline B_EQUAL_CDS & $\begin{array}{l}\text { Equally-weighted credit spread computed using both sovereign and bank CDS data. We use the BIS data } \\
\text { to select which countries to include in the measure but allow the weights to be equal. See the main text. }\end{array}$ & BIS \\
\hline B_EQUAL_RES & A fitted value from a regression of B_EQUAL_CDS on the CDS indices B_FINSNR, F_NONFIN, and S_SOVX & Own calculations \\
\hline B1 & The share of banks' claims on foreigners computed as the ratio between claims on foreigners and bank assets & IFS \& BIS \\
\hline B2 & $\begin{array}{l}\text { The share of banks' claims on the domestic residents computed as the ratio between the domestic credit and } \\
\text { bank assets }\end{array}$ & IFS \& BIS \\
\hline B3 & $\begin{array}{l}\text { The share of banks' claims on the domestic sovereign computed as the ratio between the claims on sovereign } \\
\text { and bank assets }\end{array}$ & IFS \& BIS \\
\hline C2_EDF & Median of the 5-year EDFs for domestic corporate sector & Moody's KMV \\
\hline R2_EDF & Median of the 5-year EDFs for real estate firms, real estate investment firms and construction firms & Moody's KMV \\
\hline EDF_ALL & $\begin{array}{l}\text { Median of the 5-year EDFs for the domestic corporate sector, as well as real estate firms, real estate investment } \\
\text { firms and construction firms }\end{array}$ & Moody's KMV \\
\hline GUARANTEES & Sovereign guarantees to the banking sector & See IMF (2009) \\
\hline M_CA & Current account (seasonally adjusted). Percent of GDP & $\mathrm{OECD}$, and IFS \\
\hline S_IRN_REV* & General government net interest expenditure to revenue & Fitch, Eurostat, IMF, OECD and IFS \\
\hline S_RISK & $\begin{array}{l}\text { A fitted value from a regression of sovereign CDS spread on general government gross debt to GDP, } \\
\text { long-term external debt, and the current account }\end{array}$ & See Kallestrup (2011) \\
\hline S_BIS_CDS & Exposure-weighted credit spread computed using sovereign CDS data. See the main text. & BIS \\
\hline S_BIS_RES & A fitted value from a regression of S_BIS_CDS on the CDS indices B_FINSNR, F_NONFIN, and S_SOVX & Own calculations \\
\hline S_CDS & The 5 -year sovereign CDS spread & CMA and Fitch CDS Pricing \\
\hline S_DEBT_GDP* & General government gross debt to GDP & Eurostat, OECD and IFS \\
\hline S_FDEF_GDP* & $\begin{array}{l}\text { The quarterly lending revision is calculated as the sum of the most recent year-end and year-ahead } \\
\text { budget projection by the OECD or the IMF minus the second most recent forecast for the same period } \\
\text { provided by the same organization. In quarters where they do not update a new budget projection we } \\
\text { interpolate a forecast. }\end{array}$ & OECD EO and IMF WEO \\
\hline S_GEXT_L & General government's long-term external liabilities. Percent of GDP & QEDS \\
\hline B_FINSNR & The Markit iTraxx Senior Financials index comprises 25 equally-weighted European names. & J.P. Morgan: DataQuery \\
\hline F_NONFIN & The Markit iTraxx Non-Financials index comprises 100 equally-weighted European names. & J.P. Morgan: DataQuery \\
\hline S_SOVX & $\begin{array}{l}\text { The } 5 \text {-year Itraxx SovX Western Europe index comprises } 15 \text { sovereign names where all constituents are } \\
\text { equally weighted (It is a theoretical price before the start of trading on } 28 \text { September 2009). }\end{array}$ & J.P. Morgan: DataQuery \\
\hline VPSPX & $\begin{array}{l}\text { Volatility risk premium. Computed as the difference between the VIX index and the realized volatility } \\
\text { for the S\&P } 500 \text { index over the preceding } 3 \text { months }\end{array}$ & Bloomberg \\
\hline ER3M & $\begin{array}{l}\text { Excess return for the US Stock Market. It is computed as the difference between the value-weighted } \\
\text { return on all NYSE, AMEX, and NASDAQ stocks and the three-month treasury-bill return. }\end{array}$ & $\begin{array}{l}\text { Bloomberg. The Center for } \\
\text { Research in Security Prices }\end{array}$ \\
\hline$\% \Delta$ (OISUS) & Percentage change in the 3 month US LIBOR-OIS spread & Bloomberg \\
\hline$\% \Delta(5 Y C M T)$ & Percentage change in the 5 year constant maturity treasury yields & Federal Reserve/Bloomberg \\
\hline$\% \Delta(\mathrm{HY})$ & $\begin{array}{l}\text { Percentage change in the US corporate yield spreads. The investment-grade yield spreads are computed on } \\
\text { the basis-point yield spread between BBB and AAA industrial bond indices. The percentage changes in high- } \\
\text { yield spreads are computed for the basis-point yield. The used indices represent average yields of a broad } \\
\text { cross-section of noncallable AAA-, BBB-, and BB-rated bonds with maturities approximately equal to } 5 \text { years. }\end{array}$ & Bloomberg \\
\hline$\% \Delta(\mathrm{IG})$ & $\begin{array}{l}\text { Percentage change in the US corporate yield spreads. Spread between BB and BBB industrial bond } \\
\text { indexes. See above. }\end{array}$ & Bloomberg \\
\hline
\end{tabular}




\section{Appendix B. Regression results}

Table B.1

Regressing bank CDS spreads on exposure-weighted spreads. This table reports the coefficients and t-statistics for the panel regression:

$$
\begin{aligned}
\Delta\left(\text { B_CDS }_{k, t}=\right. & \alpha_{k, 0}+\alpha_{1} \times \Delta\left(\text { B_BIS_CDS }_{k, t}+\alpha_{2}^{\prime} \times \Delta(\text { Local Bank Variables })_{k, t}\right. \\
& +\alpha_{3}^{\prime} \times \Delta(\text { Global Variables })_{t}+\alpha_{4}^{\prime} \times \Delta(\text { CDS Indices })_{t}+\varepsilon_{k, t}
\end{aligned}
$$

where $\Delta(\bullet)$ and $\% \Delta(\bullet)$ stand for first difference and percentage change of the variable over the quarter, respectively. $k$ is the index for countries and $t$ is the index for time. In column II, we simply introduce the indexes along the BIS matrix. In column III, we have regressed the BIS matrix on the CDS indices and used the residuals from this regression as a variable to explain the CDS spreads. Column IV allows for a different response in the market before and after the last quarter of 2007 by introducing a dummy variable for the period between the first quarter 2004 and the last quarter 2007. All equations are estimated by OLS with robust standard errors and country

\begin{tabular}{|c|c|c|c|c|}
\hline Variable & I & II & III & IV \\
\hline Intercept & $\begin{array}{c}-5.669 \\
(-1.497)\end{array}$ & $\begin{array}{c}-7.258^{*} \\
(-1.789)\end{array}$ & $\begin{array}{c}-6.173 \\
(-1.649)\end{array}$ & $\begin{array}{c}-7.663 \\
(-1.818)\end{array}$ \\
\hline$\Delta$ (B_BIS_CDS) & $\begin{array}{c}0.926^{* * * *} \\
(5.303)\end{array}$ & $\begin{array}{l}0.521^{* * * *} \\
(4.252)\end{array}$ & & $\begin{array}{c}0.537^{* * * *} \\
(4.136)\end{array}$ \\
\hline$\Delta($ B_BIS_CDS $) \times$ period 1 & & & & $\begin{array}{c}-0.593 \\
(-1.587)\end{array}$ \\
\hline$\Delta($ B_BIS_RES $)$ & & & $\begin{array}{l}0.231^{* *} \\
(2.717)\end{array}$ & \\
\hline$\Delta($ R2_EDF $)$ & $\begin{array}{l}12.50^{* * * *} \\
(7.384)\end{array}$ & $\begin{array}{l}11.12^{* * *} \\
(8.244)\end{array}$ & $\begin{array}{l}10.76^{* * *} \\
(8.204)\end{array}$ & $\begin{array}{c}11.12^{\text {**** }} \\
(8.358)\end{array}$ \\
\hline$\Delta\left(C 2 \_E D F\right)$ & $\begin{array}{c}-10.84 \\
(-0.540)\end{array}$ & $\begin{array}{l}-9.652 \\
(-0.481)\end{array}$ & $\begin{array}{c}-4.596 \\
(-0.186)\end{array}$ & $\begin{array}{c}-10.27 \\
(-0.520)\end{array}$ \\
\hline ER3M & $\begin{array}{c}-75.80 \\
(-1.254)\end{array}$ & $\begin{array}{c}12.09 \\
(0.189)\end{array}$ & $\begin{array}{c}-7.655 \\
(-0.117)\end{array}$ & $\begin{array}{c}17.33 \\
(0.275)\end{array}$ \\
\hline VPSPX & $\begin{array}{l}1.657^{* *} \\
(2.147)\end{array}$ & $\begin{array}{c}1.054 \\
(1.354)\end{array}$ & $\begin{array}{c}0.651 \\
(0.791)\end{array}$ & $\begin{array}{c}1.214 \\
(1.432)\end{array}$ \\
\hline$\% \triangle 5 Y C M T$ & $\begin{array}{c}-8.898 \\
(-0.865)\end{array}$ & $\begin{array}{c}-4.217 \\
(-0.453)\end{array}$ & $\begin{array}{c}-6.882 \\
(-0.826)\end{array}$ & $\begin{array}{c}-3.149 \\
(-0.345)\end{array}$ \\
\hline$\% \Delta \mathrm{HY}$ & $\begin{array}{l}-14.05 \\
(-1.007)\end{array}$ & $\begin{array}{c}-4.231 \\
(-0.571)\end{array}$ & $\begin{array}{c}13.81 \\
(1.177)\end{array}$ & $\begin{array}{c}4.443 \\
(0.765)\end{array}$ \\
\hline$\% \Delta \mathrm{IG}$ & $\begin{array}{c}-4.372 \\
(-0.440)\end{array}$ & $\begin{array}{c}9.724 \\
(0.910)\end{array}$ & $\begin{array}{c}0.415 \\
(0.038)\end{array}$ & $\begin{array}{l}12.126 \\
(1.205)\end{array}$ \\
\hline$\% \Delta$ (OISUS) & $\begin{array}{c}4.073 \\
(1.634)\end{array}$ & $\begin{array}{c}1.652 \\
(0.805)\end{array}$ & $\begin{array}{c}2.083 \\
(0.958)\end{array}$ & $\begin{array}{c}1.137 \\
(0.662)\end{array}$ \\
\hline S_RISK & $\begin{array}{c}0.869^{* * * *} \\
(3.063)\end{array}$ & $\begin{array}{c}0.774^{* * * *} \\
(2.754)\end{array}$ & $\begin{array}{c}0.766^{* * * *} \\
(2.782)\end{array}$ & $\begin{array}{c}0.180^{* * * *} \\
(2.692)\end{array}$ \\
\hline$\Delta($ S_SOVX) & & $\begin{array}{c}0.206 \\
(0.714)\end{array}$ & $\begin{array}{c}0.211 \\
(0.718)\end{array}$ & $\begin{array}{c}0.180 \\
(0.616)\end{array}$ \\
\hline$\Delta$ (F_NONFIN) & & $\begin{array}{c}0.654 \\
(-0.966)\end{array}$ & $\begin{array}{c}1.094 \\
(-1.258)\end{array}$ & $\begin{array}{c}-0.266 \\
(-1.245)\end{array}$ \\
\hline$\Delta$ (B_FINSNR) & & $\begin{array}{l}0.654^{* * * *} \\
(2.678)\end{array}$ & $\begin{array}{l}1.094^{* * * *} \\
(5.050)\end{array}$ & $\begin{array}{c}0.678^{* * * *} \\
(2.845)\end{array}$ \\
\hline Adjusted $R^{2}$ & 0.441 & 0.465 & 0.461 & 0.465 \\
\hline No. of observations & 447 & 447 & 430 & 447 \\
\hline
\end{tabular}
fixed effects. The standard errors are corrected for both heteroskedasticity and serial correlation.

*** Means significant at the $1 \%$ level.

** Means significant at the $5 \%$ level.

* Means significant at the $10 \%$ level.

Table B.2

Time effects. This table reports the coefficients and t-statistics for the panel regression:

$$
\Delta\left(\mathrm{B}_{-} \mathrm{CDS}\right)_{k, t}=\alpha_{k, 0}+\alpha_{0, t}+\alpha_{1} \times \Delta\left(\mathrm{B}_{-} \mathrm{BIS}_{-} \mathrm{CDS}\right)_{k, t}+\alpha_{2}^{\prime} \times \Delta(\text { Local Bank Variables })_{k, t}
$$

where $\Delta(\cdot)$ and $\% \Delta(\cdot)$ stand for first difference and percentage change of the variable over the quarter, respectively. $k$ is the index for countries and $t$ is the index for time. We

\begin{tabular}{|c|c|c|c|}
\hline Variables & Full sample & 2004 Q1-2007 Q4 & 2008 Q1-2010 Q4 \\
\hline Intercept & $\begin{array}{c}6.878^{* * * *} \\
(7.056)\end{array}$ & $\begin{array}{l}1.791^{* * * *} \\
(8.708)\end{array}$ & $\begin{array}{c}10.294^{* * *} \\
(2.532)\end{array}$ \\
\hline$\Delta($ B_BIS_CDS $)$ & $\begin{array}{l}0.440^{* * *} \\
(2.591)\end{array}$ & $\begin{array}{c}0.052 \\
(0.675)\end{array}$ & $\begin{array}{c}0.453^{* * *} \\
(2.596)\end{array}$ \\
\hline$\Delta$ (R2_EDF) & $\begin{array}{c}11.458^{* * * *} \\
(8.652)\end{array}$ & $\begin{array}{l}1.016^{*} \\
(1.649)\end{array}$ & $\begin{array}{c}12.491^{* * * *} \\
(8.685)\end{array}$ \\
\hline$\Delta$ (C2_EDF) & 0.121 & 0.606 & -18.183 \\
\hline
\end{tabular}
perform the analysis first for the whole sample from the first quarter of 2004 to the last quarter of 2010. Afterward we perform the same analysis on sub-periods. All equations are estimated by OLS with robust standard errors, and country and time fixed effects. The standard errors are corrected for both heteroskedasticity and serial correlation. 
Table B.2 (continued)

\begin{tabular}{|c|c|c|c|}
\hline Variables & Full sample & 2004 Q1-2007 Q4 & 2008 Q1-2010 Q4 \\
\hline \multirow{3}{*}{$\Delta\left(\mathrm{S} \_\right.$RISK $)$} & $(0.004)$ & $(0.302)$ & $(-0.555)$ \\
\hline & $0.849^{* * * *}$ & 0.008 & $0.276^{* * *}$ \\
\hline & (3.601) & $(0.389)$ & (3.933) \\
\hline Adjusted $R^{2}$ & 0.453 & 0.675 & 0.457 \\
\hline No. of observations & 447 & 243 & 204 \\
\hline
\end{tabular}

*** Means significant at the $1 \%$ level.

** Means significant at the $5 \%$ level.

* Means significant at the $10 \%$ level.

Table B.3

Countries with strong/weak connections. This table reports the coefficients and t-statistics for the panel regression:

$$
\begin{aligned}
& \Delta\left(\text { B_CDS }_{k, t}=\alpha_{k, 0}+\alpha_{1} \times \Delta\left(\text { B_BIS_CDS }_{k, t}+\alpha_{2}^{\prime} \times \Delta(\text { Local Bank Variables })_{k, t}\right.\right. \\
& +\alpha_{3}^{\prime} \times \Delta(\text { Global Variables })_{t}+\alpha_{4} \times \Delta(\text { CDS Financials Index })_{t}+\varepsilon_{k, t}
\end{aligned}
$$

where $\Delta(\bullet)$ and $\% \Delta(\bullet)$ stand for first difference and percentage change of the variable over the quarter, respectively. $k$ is the index for countries and $t$ is the index for time. We perform the analysis on three sub-groups: countries whose foreign exposure weights more than $40 \%$ of their portfolio, whose foreign exposure (FExp) weights less than $40 \%$ of their portfolio and all the countries except the USA. In the first group, we have Austria, Belgium, Switzerland, Germany, France, Great Britain, Ireland, the Netherlands, and Sweden. In the second group, we have Australia, Denmark, Spain, Greece, Italy, Japan, Portugal, and the United States. All equations are estimated by

\begin{tabular}{|c|c|c|c|}
\hline Variable & FExp $\geq 40 \%$ & FExp $\leq 40 \%$ & No USA \\
\hline Intercept & $\begin{array}{c}1.259 \\
(0.445)\end{array}$ & $\begin{array}{c}-11.69^{* * *} \\
(-2.784)\end{array}$ & $\begin{array}{c}-6.856^{*} \\
(-1.649)\end{array}$ \\
\hline$\Delta($ B_BIS_CDS $)$ & $\begin{array}{c}0.496^{* *} \\
(2.38)\end{array}$ & $\begin{array}{c}0.5^{* *} \\
(2.01)\end{array}$ & $\begin{array}{c}0.564^{* * *} \\
(4.428)\end{array}$ \\
\hline$\Delta$ (R2_EDF) & $\begin{array}{c}13.36^{* * * *} \\
(10.16)\end{array}$ & $\begin{array}{c}2.908 \\
(0.543)\end{array}$ & $\begin{array}{c}11.38^{* * * *} \\
(7.413)\end{array}$ \\
\hline$\Delta\left(\mathrm{C} 2 \_\mathrm{EDF}\right)$ & $\begin{array}{l}-75.85^{* * *} \\
(-4.403)\end{array}$ & $\begin{array}{c}10.98 \\
(0.584)\end{array}$ & $\begin{array}{c}-13.04 \\
(-0.522)\end{array}$ \\
\hline ER3M & $\begin{array}{l}2.727 \\
(0.05)\end{array}$ & $\begin{array}{c}45.12 \\
(0.302)\end{array}$ & $\begin{array}{c}23.76 \\
(0.388)\end{array}$ \\
\hline VPSPX & $\begin{array}{l}-1.125^{* *} \\
(-2.109)\end{array}$ & $\begin{array}{l}2.096^{*} \\
(1.882)\end{array}$ & $\begin{array}{c}1.205 \\
(1.466)\end{array}$ \\
\hline$\% \triangle 5 Y C M T$ & $\begin{array}{c}4.274 \\
(0.273)\end{array}$ & $\begin{array}{c}7.364 \\
(0.386)\end{array}$ & $\begin{array}{c}1.173 \\
(0.088)\end{array}$ \\
\hline$\% \Delta \mathrm{HY}$ & $\begin{array}{c}-19.3 \\
(-1.645)\end{array}$ & $\begin{array}{c}13.27 \\
(0.717)\end{array}$ & $\begin{array}{c}-4.506 \\
(-0.394)\end{array}$ \\
\hline$\% \Delta \mathrm{IG}$ & $\begin{array}{c}21.61 \\
(1.593)\end{array}$ & $\begin{array}{l}-8.789 \\
(-0.39)\end{array}$ & $\begin{array}{c}12.27 \\
(1.002)\end{array}$ \\
\hline$\% \Delta$ (OISUS) & $\begin{array}{c}2.811 \\
(1.161)\end{array}$ & $\begin{array}{c}1.604 \\
(0.394)\end{array}$ & $\begin{array}{c}2.028 \\
(0.871)\end{array}$ \\
\hline S_RISK & $\begin{array}{c}0.167 \\
(1.277)\end{array}$ & $\begin{array}{l}1.229^{* * * *} \\
(4.477)\end{array}$ & $\begin{array}{c}0.838^{* * * *} \\
(2.945)\end{array}$ \\
\hline$\Delta$ (B_FINSNR) & $\begin{array}{c}0.815^{*} \\
(1.796)\end{array}$ & $\begin{array}{c}0.491^{*} \\
(1.780)\end{array}$ & $\begin{array}{l}0.622^{* * *} \\
(2.470)\end{array}$ \\
\hline Adjusted $R^{2}$ & 0.469 & 0.525 & 0.455 \\
\hline No. of observations & 235 & 212 & 420 \\
\hline
\end{tabular}
OLS with robust standard errors, and country fixed effects. The standard errors are corrected for both heteroskedasticity and serial correlation.

*** Means significant at the $1 \%$ level.

** Means significant at the $5 \%$ level.

* Means significant at the $10 \%$ level.

Table B.4

Allowing for different weights on the local variables and the BIS exposure matrix. This table reports the coefficients and t-statistics for the panel regression:

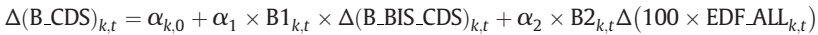

$$
\begin{aligned}
& \alpha_{3} \times \mathrm{B}_{k, t} \times \mathrm{S} \_ \text {RISK }_{k, t}+\alpha_{4}^{\prime} \times \Delta(\text { Global Variables })_{t}+\varepsilon_{k, t}
\end{aligned}
$$

where $\Delta(\bullet)$ and $\% \Delta(\bullet)$ stand for first difference and percentage change of the variable over the quarter, respectively. $k$ is the index for countries and $t$ is the index for time.

\begin{tabular}{|c|c|c|c|}
\hline Variable & Full sample & Q1 2004-Q4 2007 & Q1 2008-Q4 2010 \\
\hline Intercept & $\begin{array}{c}-5.871 \\
(-1.625)\end{array}$ & $\begin{array}{c}-0.641 \\
(-1.416)\end{array}$ & $\begin{array}{c}-8.047 \\
(-1.260)\end{array}$ \\
\hline B1 $\times \Delta($ B_BIS_CDS $)$ & $1.225^{* * *}$ & $0.413^{*}$ & $1.250^{* * *}$ \\
\hline
\end{tabular}
We perform the analysis first for the whole sample and on sub-periods. All equations are estimated by OLS with robust standard errors and country fixed effects. The standard errors are corrected for both heteroskedasticity and serial correlation. 
Table B.4 (continued)

\begin{tabular}{|c|c|c|c|}
\hline Variable & Full sample & Q1 2004-Q4 2007 & Q1 2008-Q4 2010 \\
\hline & (3.869) & $(1.874)$ & (3.025) \\
\hline \multirow[t]{2}{*}{$\mathrm{B} 2 \times \Delta(100 \times$ EDF_ALL $)$} & $0.175^{* * *}$ & $0.018^{* * *}$ & $0.187^{* * *}$ \\
\hline & $(3.052)$ & $(4.096)$ & $(2.747)$ \\
\hline \multirow[t]{2}{*}{ B3 × S_RISK } & $6.624^{* *}$ & 0.072 & $9.535^{* * *}$ \\
\hline & $(2.078)$ & $(0.635)$ & $(3.049)$ \\
\hline \multirow[t]{2}{*}{ ER3M } & 20.12 & $25.98^{* *}$ & 76.06 \\
\hline & $(0.258)$ & $(1.979)$ & $(0.666)$ \\
\hline \multirow[t]{2}{*}{ VPSPX } & 0.990 & 0.207 & 0.707 \\
\hline & $(1.458)$ & $(1.401)$ & $(0.419)$ \\
\hline \multirow[t]{2}{*}{$\% \triangle 5 Y C M T$} & -1.902 & $4.234^{*}$ & 5.645 \\
\hline & $(-0.136)$ & $(1.875)$ & $(0.260)$ \\
\hline \multirow[t]{2}{*}{$\% \Delta \mathrm{HY}$} & -5.582 & $2.968^{*}$ & -18.44 \\
\hline & $(-0.973)$ & $(1.827)$ & $(-0.253)$ \\
\hline \multirow[t]{2}{*}{$\% \Delta \mathrm{IG}$} & 8.658 & 1.491 & 7.387 \\
\hline & $(1.071)$ & $(1.194)$ & $(0.284)$ \\
\hline \multirow[t]{2}{*}{$\% \Delta$ (OISUS) } & 2.056 & $0.810^{* *}$ & $12.03^{* *}$ \\
\hline & $(1.214)$ & $(2.585)$ & $(2.379)$ \\
\hline \multirow[t]{2}{*}{$\Delta\left(\mathrm{S} \_\right.$SOVX $)$} & 0.200 & $1.886^{* * *}$ & 0.024 \\
\hline & $(0.734)$ & $(2.908)$ & $(0.066)$ \\
\hline \multirow[t]{2}{*}{$\Delta($ F_NONFIN $)$} & -0.199 & $0.187^{*}$ & 0.085 \\
\hline & $(-0.979)$ & $(1.676)$ & $(0.230)$ \\
\hline \multirow[t]{2}{*}{$\Delta$ (B_FINSNR) } & $0.685^{* * *}$ & 0.070 & $0.607^{*}$ \\
\hline & $(2.622)$ & $(0.604)$ & $(1.813)$ \\
\hline Adjusted $R^{2}$ & 0.499 & 0.663 & 0.542 \\
\hline No. of observations & 447 & 243 & 204 \\
\hline
\end{tabular}

*** Means significant at the $1 \%$ level.

** Means significant at the $5 \%$ level.

* Means significant at the $10 \%$ level.

Table B.5

Excluding the biggest 5 exposures. In columns I and II, we repeat the equations estimated in Table B.1 but we are dividing the BIS matrix by the share of exposure explained. We repeat the estimation using a BIS exposure matrix from which we have excluded the biggest 5 exposures, also weighting by the share of exposure explained by the new matrix.

\begin{tabular}{|c|c|c|c|c|}
\hline Variable & I & II & III & IV \\
\hline Intercept & $\begin{array}{c}-5.663 \\
(-1.498)\end{array}$ & $\begin{array}{l}-7.255^{* * *} \\
(-1.789)\end{array}$ & $\begin{array}{c}-5.181 \\
(-1.289)\end{array}$ & $\begin{array}{l}-8.086^{*} \\
(-1.955)\end{array}$ \\
\hline$\Delta($ B_BIS_CDS)/SHARE & $\begin{array}{l}0.794^{* * *} \\
(5.286)\end{array}$ & $\begin{array}{l}0.449^{* * *} \\
(4.331)\end{array}$ & & \\
\hline$\Delta$ (B_BIS_NOT5)/SHARE & & & $\begin{array}{c}0.308^{* * *} \\
(2.848)\end{array}$ & $\begin{array}{c}0.047 \\
(0.463)\end{array}$ \\
\hline$\Delta\left(\mathrm{R} 2 \_\mathrm{EDF}\right)$ & $\begin{array}{l}12.50^{* * *} \\
(7.445)\end{array}$ & $\begin{array}{l}11.12^{* * *} \\
(8.258)\end{array}$ & $\begin{array}{l}13.00^{* * * *} \\
(8.386)\end{array}$ & $\begin{array}{l}10.43^{* * * *} \\
(8.008)\end{array}$ \\
\hline$\Delta\left(\mathrm{C} 2 \_\mathrm{EDF}\right)$ & $\begin{array}{c}-10.92 \\
(-0.545)\end{array}$ & $\begin{array}{c}-9.710 \\
(-0.484)\end{array}$ & $\begin{array}{c}-14.16 \\
(-0.546)\end{array}$ & $\begin{array}{c}-7.478 \\
(-0.347)\end{array}$ \\
\hline ER3M & $\begin{array}{c}-76.16 \\
(-1.262)\end{array}$ & $\begin{array}{c}12.15 \\
(0.190)\end{array}$ & $\begin{array}{l}-276.3^{* * *} \\
(-4.924)\end{array}$ & $\begin{array}{c}-39.35 \\
(-0.654)\end{array}$ \\
\hline VPSPX & $\begin{array}{l}1.658^{* *} \\
(2.147)\end{array}$ & $\begin{array}{c}1.054 \\
(1.353)\end{array}$ & $\begin{array}{l}2.154^{* * *} \\
(2.879)\end{array}$ & $\begin{array}{c}1.197 \\
(1.563)\end{array}$ \\
\hline$\% \triangle 5 Y C M T$ & $\begin{array}{c}-14.12 \\
(-1.011)\end{array}$ & $\begin{array}{c}-4.231 \\
(-0.571)\end{array}$ & $\begin{array}{l}-16.31^{*} \\
(-1.757)\end{array}$ & $\begin{array}{c}-7.618 \\
(-0.831)\end{array}$ \\
\hline$\% \Delta \mathrm{HY}$ & $\begin{array}{c}-4.380 \\
(-0.441)\end{array}$ & $\begin{array}{c}9.708 \\
(0.910)\end{array}$ & $\begin{array}{l}-41.59^{* * *} \\
(-3.476)\end{array}$ & $\begin{array}{c}-4.064 \\
(-0.576)\end{array}$ \\
\hline$\% \Delta \mathrm{IG}$ & $\begin{array}{l}-8.901 \\
(-0.864)\end{array}$ & $\begin{array}{c}-4.218 \\
(-0.452)\end{array}$ & $\begin{array}{c}-11.18 \\
(-1.355)\end{array}$ & $\begin{array}{c}18.92 \\
(1.643)\end{array}$ \\
\hline$\% \Delta$ (OISUS) & $\begin{array}{c}4.083 \\
(1.634)\end{array}$ & $\begin{array}{c}1.652 \\
(0.805)\end{array}$ & $\begin{array}{l}9.806^{* * *} \\
(4.880)\end{array}$ & $\begin{array}{c}1.830 \\
(0.886)\end{array}$ \\
\hline S_RISK & $\begin{array}{l}0.869^{* * *} \\
(3.065)\end{array}$ & $\begin{array}{l}0.773^{* * * *} \\
(2.756)\end{array}$ & $\begin{array}{l}0.954^{* * *} \\
(3.258)\end{array}$ & $\begin{array}{l}0.785^{* * *} \\
(2.706)\end{array}$ \\
\hline$\Delta($ B_FINSNR $)$ & & $\begin{array}{l}0.653^{\text {**** }} \\
(2.697)\end{array}$ & & $\begin{array}{l}1.058^{* * *} \\
(3.853)\end{array}$ \\
\hline$\Delta$ (F_NONFIN $)$ & & $\begin{array}{l}-0.219 \\
(0.715)\end{array}$ & & $\begin{array}{c}-0.388 \\
(0.592)\end{array}$ \\
\hline$\Delta\left(\mathrm{S} \_\right.$SOVX $)$ & & $\begin{array}{c}-0.219 \\
(-0.970)\end{array}$ & & $\begin{array}{c}-0.388 \\
(-1.531)\end{array}$ \\
\hline Adjusted $R^{2}$ & 0.441 & 0.465 & 0.369 & 0.447 \\
\hline No. of observations & 447 & 447 & 447 & 447 \\
\hline
\end{tabular}

**** Means significant at the $1 \%$ level.

** Means significant at the $5 \%$ level.

* Means significant at the $10 \%$ level. 


\section{Table B.6}

Robustness tests. In the first two columns, we repeat the equations estimated in Table B.1, columns II and III but we are using an exposure matrix where we weigh equally all the exposures. Column III reports the results obtained by running the panel regression as in Table B.2.

Columns IV and V report the results for the estimated in Table B.1, columns II and III but we are using an exposure matrix where we use only sovereign CDS to measure the riskiness of investments. The last column report results were obtained by running the panel regression as in Table B.2.

$\Delta(\bullet)$ and $\% \Delta(\bullet)$ stand for first difference and percentage change of the variable over the quarter, respectively. $k$ is the index for countries and $t$ is the index for time. Our sample runs from the first quarter of 2006 to the last quarter of 2010 . All equations are estimated by OLS with robust standard errors, and country fixed effects. The last column is estimated using also time effects. The standard errors are corrected for both heteroskedasticity and serial correlation.

\begin{tabular}{|c|c|c|c|c|c|c|}
\hline a & I & II & III & IV & V & VI \\
\hline Intercept & $\begin{array}{c}-7.402^{*} \\
(-1.803)\end{array}$ & $\begin{array}{c}-6.669^{*} \\
(-1.727)\end{array}$ & $\begin{array}{c}0.443 \\
(0.134)\end{array}$ & $\begin{array}{c}-2.455 \\
(1.34)\end{array}$ & $\begin{array}{c}-3.263 \\
(-0.834)\end{array}$ & $\begin{array}{c}8.519^{* * * *} \\
(4.076)\end{array}$ \\
\hline$\Delta($ B_EQUAL_CDS $)$ & $\begin{array}{c}0.396^{* * *} \\
(3.105)\end{array}$ & & $\begin{array}{l}0.410^{* *} \\
(2.151)\end{array}$ & & & \\
\hline$\Delta($ B_EQUAL_RES $)$ & & $\begin{array}{l}0.167^{\text {** }} \\
(2.029)\end{array}$ & & & & \\
\hline$\Delta\left(\mathrm{S} \_B I S \_C D S\right)$ & & & & $\begin{array}{c}0.798^{* * *} \\
(2.982)\end{array}$ & & $\begin{array}{c}0.978^{* * * *} \\
(3.059)\end{array}$ \\
\hline$\Delta\left(\mathrm{S} \_B I S \_R E S\right)$ & & & & & $\begin{array}{c}0.538^{* * *} \\
(2.261)\end{array}$ & \\
\hline$\Delta($ R2_EDF $)$ & $\begin{array}{l}11.22^{* * *} \\
(8.724)\end{array}$ & $\begin{array}{l}10.86^{* * *} \\
(8.197)\end{array}$ & $\begin{array}{l}12.183^{* * *} \\
(10.443)\end{array}$ & $\begin{array}{c}9.159 * \\
(1.875)\end{array}$ & $\begin{array}{c}11.453^{* * *} \\
(8.806)\end{array}$ & $\begin{array}{l}10.64^{* * * *} \\
(6.652)\end{array}$ \\
\hline$\Delta$ (C2_EDF) & $\begin{array}{c}-11.71 \\
(-0.581)\end{array}$ & $\begin{array}{c}-5.753 \\
(-0.230)\end{array}$ & $\begin{array}{c}-5.606 \\
(-0.233)\end{array}$ & $\begin{array}{c}4.072 \\
(0.136)\end{array}$ & $\begin{array}{c}-21.206 \\
(0.587)\end{array}$ & $\begin{array}{l}8.996 \\
(0.23)\end{array}$ \\
\hline S_RISK & $\begin{array}{l}0.799^{* * *} \\
(2.740)\end{array}$ & $\begin{array}{l}0.785^{* * *} \\
(2.781)\end{array}$ & $\begin{array}{l}0.85^{* * *} \\
(2.920)\end{array}$ & $\begin{array}{l}0.348^{* *} \\
(2.408)\end{array}$ & $\begin{array}{l}0.907^{* * *} \\
(2.818)\end{array}$ & $\begin{array}{c}0.372^{*} \\
(1.816)\end{array}$ \\
\hline Global variables & Yes & Yes & & Yes & Yes & \\
\hline CDS indices & Yes & Yes & & Yes & Yes & \\
\hline Time fixed effects & & & Yes & & & Yes \\
\hline Adjusted $R^{2}$ & 0.460 & 0.452 & 0.452 & 0.430 & 0.450 & 0.428 \\
\hline No. of observations & 447 & 447 & 430 & 447 & 447 & 430 \\
\hline
\end{tabular}

*** Means significant at the $1 \%$ level.

** Means significant at the $5 \%$ level.

* Means significant at the $10 \%$ level.

Table B.7

The sovereign CDS equation with indices. This table reports the coefficients and t-statistics for the panel regression:

$$
\begin{aligned}
\Delta\left(\mathrm{S}_{-} \mathrm{CDS}\right)_{k, t}= & \alpha_{k, 0}+\alpha_{1}^{\prime} \times \Delta(\text { Domestic Government Variables })_{k, t}+\alpha_{2}^{\prime} \times(\text { Guarantees })_{k, t} \\
& +\alpha_{3}^{\prime} \times \Delta(\text { Global Variables })_{t}+\alpha_{4}^{\prime} \times \Delta(\text { CDS Indices })_{t}+\varepsilon_{k, t}
\end{aligned}
$$

where $\Delta(\cdot)$ and $\% \Delta(\cdot)$ stand for first difference and percentage change of the variable over the quarter, respectively. $k$ is the index for countries and $t$ is the index for time. In columns III and IV we use the EDFs as a measure of risk for the banking systems instead of the CDS's. Equations reported in columns I to IV are estimated with OLS. Column V is estimated with 2SLS where the change in central bank collateralized loans is an instrument for $\Delta\left(B_{-} C D S\right)$. Country fixed effects and robust standard errors

\begin{tabular}{|c|c|c|c|c|c|}
\hline Variable & I & II & III & IV & V \\
\hline Intercept & $\begin{array}{c}1.218 \\
(0.664)\end{array}$ & $\begin{array}{c}0.994 \\
(0.547)\end{array}$ & $\begin{array}{c}-0.686 \\
(-0.248)\end{array}$ & $\begin{array}{c}-0.945 \\
(-0.346)\end{array}$ & $\begin{array}{l}1.687 \\
(0.8)\end{array}$ \\
\hline$\Delta$ (S_IRN_REV) & $\begin{array}{c}-4.517^{*} \\
(-1.691)\end{array}$ & $\begin{array}{c}-4.467 \\
(-1.638)\end{array}$ & $\begin{array}{c}-4.539 \\
(-1.378)\end{array}$ & $\begin{array}{c}-4.49 \\
(-1.348)\end{array}$ & $\begin{array}{l}-4.595^{*} \\
(-1.951)\end{array}$ \\
\hline S_FDEF_GDP & $\begin{array}{c}0.482 \\
(1.582)\end{array}$ & $\begin{array}{c}0.574^{*} \\
(1.802)\end{array}$ & $\begin{array}{l}-0.642 \\
(-0.908)\end{array}$ & $\begin{array}{l}-0.521 \\
(-0.749)\end{array}$ & $\begin{array}{c}1.193 \\
(1.089)\end{array}$ \\
\hline$\Delta($ S_GEXT_L) & $\begin{array}{c}-8.039^{* *} \\
(-2.5)\end{array}$ & $\begin{array}{l}-8.04^{* *} \\
(-2.48)\end{array}$ & $\begin{array}{l}-9.531^{* * *} \\
(-2.361)\end{array}$ & $\begin{array}{l}-9.532^{* *} \\
(-2.343)\end{array}$ & $\begin{array}{l}-7.511^{* *} \\
(-2.273)\end{array}$ \\
\hline$\Delta\left(\mathrm{M}_{-} \mathrm{CA}\right)$ & $\begin{array}{c}4.528^{*} \\
(1.733)\end{array}$ & $\begin{array}{l}4.349^{*} \\
(1.661)\end{array}$ & $\begin{array}{c}5.213^{*} \\
(1.757)\end{array}$ & $\begin{array}{c}5.005^{*} \\
(1.663)\end{array}$ & $\begin{array}{c}4.111^{*} \\
(1.589)\end{array}$ \\
\hline$\Delta($ S_DEBT_GDP $)$ & $\begin{array}{l}3.006^{* * * *} \\
(4.813)\end{array}$ & $\begin{array}{l}2.947^{* * * *} \\
(4.548)\end{array}$ & $\begin{array}{c}2.557^{* * * *} \\
(5.612)\end{array}$ & $\begin{array}{l}2.484^{* * * *} \\
(5.005)\end{array}$ & $\begin{array}{c}3.038^{* * * *} \\
(3.464)\end{array}$ \\
\hline GUARANTEES & & $\begin{array}{l}0.109^{* * *} \\
(2.167)\end{array}$ & & $\begin{array}{l}0.127^{* * *} \\
(2.208)\end{array}$ & $\begin{array}{l}0.111^{* *} \\
(2.043)\end{array}$ \\
\hline$\Delta\left(\mathrm{B}_{-} \mathrm{CDS}\right) \times$ B_GDP & $\begin{array}{c}0.075^{* * *} \\
(4.097)\end{array}$ & $\begin{array}{l}0.075^{* * * *} \\
(4.135)\end{array}$ & & & $\begin{array}{c}0.101^{* * * *} \\
(11.14)\end{array}$ \\
\hline$\Delta($ B_EDF $) \times$ B_GDP & & & $\begin{array}{l}1.485^{* * *} \\
(7.215)\end{array}$ & $\begin{array}{l}1.521^{* * * *} \\
(7.458)\end{array}$ & \\
\hline ER3M & $\begin{array}{l}11.06 \\
(0.599)\end{array}$ & $\begin{array}{c}10.21 \\
(0.554)\end{array}$ & $\begin{array}{c}0.015 \\
(0.001)\end{array}$ & $\begin{array}{c}-1.132 \\
(-0.058)\end{array}$ & $\begin{array}{c}11.89 \\
(0.588)\end{array}$ \\
\hline VPSPX & $\begin{array}{l}0.206 \\
(0.63)\end{array}$ & $\begin{array}{l}0.273 \\
(0.85)\end{array}$ & $\begin{array}{l}0.777 \\
(1.52)\end{array}$ & $\begin{array}{c}0.858^{*} \\
(1.711)\end{array}$ & $\begin{array}{c}0.106 \\
(0.293)\end{array}$ \\
\hline$\% \triangle 5 Y C M T$ & $\begin{array}{l}-23.15^{* * *} \\
(-2.617)\end{array}$ & $\begin{array}{c}-22.823^{* * *} \\
(-2.593)\end{array}$ & $\begin{array}{l}-28.98^{* * * *} \\
(-2.717)\end{array}$ & $\begin{array}{c}-28.587^{* * *} \\
(-2.674)\end{array}$ & $\begin{array}{c}-20.631^{* * *} \\
(-2.636)\end{array}$ \\
\hline
\end{tabular}
are used for all the estimations. The standard errors are corrected for both heteroskedasticity and serial correlation. 
Table B.7 (continued)

\begin{tabular}{|c|c|c|c|c|c|}
\hline Variable & I & II & III & IV & V \\
\hline \multirow[t]{2}{*}{$\% \Delta \mathrm{HY}$} & 9.278 & 9.210 & $10.949^{* *}$ & $10.911^{*}$ & 9.219 \\
\hline & $(1.594)$ & $(1.574)$ & $(1.976)$ & $(1.961)$ & $(1.559)$ \\
\hline \multirow[t]{2}{*}{$\% \Delta \mathrm{IG}$} & 6.965 & -2.088 & $14.880^{* *}$ & $-2.112^{* *}$ & -2.114 \\
\hline & $(1.529)$ & $(1.547)$ & $(2.555)$ & $(2.554)$ & $(0.834)$ \\
\hline \multirow[t]{2}{*}{$\% \Delta$ OISUS } & $0.718^{* * *}$ & $-2.088^{* * *}$ & $0.826^{* * *}$ & $-2.112^{* * *}$ & $-2.114^{* * *}$ \\
\hline & $(-3.166)$ & $(-3.044)$ & $(-3.063)$ & $(-2.971)$ & $(-2.944)$ \\
\hline \multirow[t]{2}{*}{$\Delta\left(\mathrm{S} \_\right.$SOVX $)$} & $0.718^{* * *}$ & $0.700^{* * *}$ & $0.826^{* * *}$ & $0.805^{* * *}$ & $0.661^{* * *}$ \\
\hline & $(4.563)$ & $(4.307)$ & $(4.237)$ & $(4.012)$ & $(3.561)$ \\
\hline \multirow[t]{2}{*}{$\Delta$ (F_NONFIN $)$} & -0.030 & $-0.045^{* *}$ & -0.140 & -0.157 & -0.004 \\
\hline & $(-0.296)$ & $(-0.451)$ & $(-1.150)$ & $(-1.331)$ & $(-0.034)$ \\
\hline \multirow[t]{2}{*}{$\Delta$ (B_FINSNR) } & $-0193^{* * *}$ & $-0.174^{* * *}$ & 0.073 & 0.094 & $-0.280^{* * *}$ \\
\hline & $(-2.788)$ & $(-2.442)$ & $(0.997)$ & $(1.307)$ & $(-2.291)$ \\
\hline Adjusted $R^{2}$ & 0.615 & 0.615 & 0.527 & 0.528 & 0.603 \\
\hline No. of observations & 424 & 424 & 424 & 424 & 424 \\
\hline
\end{tabular}

*** Means significant at the $1 \%$ level.

** Means significant at the $5 \%$ level.

* Means significant at the $10 \%$ level.

\section{Table B.8}

Sovereign equation on sub-periods and with time fixed effects. The first two columns report the coefficients and t-statistics for the following panel regression, performed on two subperiods:

$$
\begin{aligned}
\Delta\left(\mathrm{S}_{-} \mathrm{CDS}\right)_{k, t}= & \alpha_{k, 0}+\alpha_{1}^{\prime} \times \Delta(\text { Domestic Government Variables })_{k, t}+\alpha_{2}^{\prime} \times(\text { Guarantees })_{k, t} \\
& +\alpha_{3}^{\prime} \times \Delta(\text { Global Variables })_{t}+\alpha_{4}^{\prime} \times \Delta(\text { CDS Indices })_{t}+\varepsilon_{k, t}
\end{aligned}
$$

The last three columns report the coefficients and t-statistics for the panel regression:

$$
\Delta\left(\mathrm{S}_{-} \mathrm{CDS}\right)_{k, t}=\alpha_{k, 0}+\alpha_{0, t}+\alpha_{1} \times \text { Guarantees }_{k, t}+\alpha_{2}^{\prime} \times \Delta(\text { Local Government Variables })_{k, t}+\varepsilon_{k, t}
$$

We perform the analysis first for the whole sample from the first quarter of 2004 to the last quarter of 2010 . Afterward we perform the same analysis on sub-periods. These regressions are performed with time fixed effects.

$\Delta(\bullet)$ and $\% \Delta(\bullet)$ stand for first difference and percentage change of the variable over the quarter, respectively. $k$ is the index for countries and $t$ is the index for time. All

\begin{tabular}{|c|c|c|c|c|c|}
\hline Variable & Q1 2004-Q4 2007 & Q1 2008-Q4 2010 & $\begin{array}{l}\text { Time effects, } \\
\text { Q1 2004-Q4 } 2010\end{array}$ & $\begin{array}{c}\text { Time effects, } \\
\text { Q1 2004-Q4 } 2007\end{array}$ & $\begin{array}{l}\text { Time effects, } \\
\text { Q1 2008-Q4 } 2010\end{array}$ \\
\hline Intercept & $\begin{array}{c}-0.136 \\
(-0.464)\end{array}$ & $\begin{array}{c}12.86 \\
(1.636)\end{array}$ & $\begin{array}{l}4.294^{*} \\
(8.56)\end{array}$ & $\begin{array}{c}0.581 \\
(1.596)\end{array}$ & $\begin{array}{l}9.872 * \\
(3.545)\end{array}$ \\
\hline$\Delta\left(\mathrm{S} \_I R N \_R E V\right)$ & $\begin{array}{c}-0.56^{*} \\
(-1.706)\end{array}$ & $\begin{array}{l}-6.136 \\
(-1.532)\end{array}$ & $\begin{array}{l}-4.444^{*} \\
(-1.829)\end{array}$ & $\begin{array}{c}-0.476 \\
(-1.431)\end{array}$ & $\begin{array}{c}-5.314 \\
(-1.523)\end{array}$ \\
\hline S_FDEF_GDP & $\begin{array}{c}-0.187 \\
(-0.863)\end{array}$ & $\begin{array}{c}2.691 \\
(1.457)\end{array}$ & $\begin{array}{c}2.315 \\
(1.496)\end{array}$ & $\begin{array}{c}-0.18 \\
(-0.784)\end{array}$ & $\begin{array}{c}2.928 \\
(1.486)\end{array}$ \\
\hline$\Delta($ S_GEXT_L) & $\begin{array}{c}0.03 \\
(0.243)\end{array}$ & $\begin{array}{l}-10.96^{* *} \\
(-2.204)\end{array}$ & $\begin{array}{l}-8.374^{* *} \\
(-2.096)\end{array}$ & $\begin{array}{c}0.094 \\
(0.617)\end{array}$ & $\begin{array}{l}-11.22^{* *} \\
(-2.209)\end{array}$ \\
\hline$\Delta\left(\mathrm{M} \_\mathrm{CA}\right)$ & $\begin{array}{c}0.151 \\
(0.368)\end{array}$ & $\begin{array}{c}1.87 \\
(0.744)\end{array}$ & $\begin{array}{c}4.419 \\
(1.543)\end{array}$ & $\begin{array}{c}0.107 \\
(0.286)\end{array}$ & $\begin{array}{c}3.282 \\
(1.027)\end{array}$ \\
\hline$\Delta($ S_DEBT_GDP $)$ & $\begin{array}{c}0.106 \\
(0.934)\end{array}$ & $\begin{array}{l}2.581 \\
(1.65)\end{array}$ & $\begin{array}{l}4.876^{* *} \\
(2.123)\end{array}$ & $\begin{array}{c}0.048 \\
(0.489)\end{array}$ & $\begin{array}{l}5.214^{*} \\
(1.926)\end{array}$ \\
\hline Guarantees & & $\begin{array}{l}0.129^{* *} \\
(2.469)\end{array}$ & $\begin{array}{c}0.076 \\
(0.837)\end{array}$ & & $\begin{array}{c}0.102 \\
(1.304)\end{array}$ \\
\hline$\Delta($ B_CDS $) \times$ B_GDP & $\begin{array}{c}-0.027 \\
(-0.537)\end{array}$ & $\begin{array}{l}0.104^{* * * *} \\
(6.816)\end{array}$ & $\begin{array}{c}0.108^{* * *} \\
(10.6)\end{array}$ & $\begin{array}{l}-0.031 \\
(-0.642)\end{array}$ & $\begin{array}{l}0.101^{* * * *} \\
(6.952)\end{array}$ \\
\hline Global variables and CDS index & Yes & Yes & & & \\
\hline Time effects & & & Yes & Yes & Yes \\
\hline Adjusted $R^{2}$ & 0.269 & 0.620 & 0.573 & 0.260 & 0.603 \\
\hline No. of observations & 225 & 199 & 424 & 225 & 199 \\
\hline
\end{tabular}
equations are estimated with 2SLS where the change in central bank colleralised loans is an instrument for $\Delta$ (B_CDS). The regressions are estimated with country fixed effects and robust standard errors. The standard errors are corrected for both heteroskedasticity and serial correlation.

*** Means significant at the $1 \%$ level.

** Means significant at the 5\% level.

* Means significant at the $10 \%$ level. 
Table B.9

Robustness check. Sovereign equation on sub-periods and with time fixed effects. The first three columns report the coefficients and t-statistics for the following panel regression, performed on the overall sample and two subperiods:

$$
\begin{aligned}
\Delta\left(\mathrm{S}_{-} \mathrm{CDS}\right)_{k, t}= & \alpha_{k, 0}+\alpha_{1}^{\prime} \times \Delta(\text { Domestic Government Variables })_{k, t}+\alpha_{2}^{\prime} \times(\text { Guarantees })_{k, t} \\
& +\alpha_{3}^{\prime} \times \Delta(\text { Global Variables })_{t}+\alpha_{4}^{\prime} \times \Delta(\text { CDS Indices })_{t}+\varepsilon_{k, t}
\end{aligned}
$$

The last three columns report the coefficients and t-statistics for the panel regression:

$$
\Delta\left(\mathrm{S}_{-} \mathrm{CDS}\right)_{k, t}=\alpha_{k, 0}+\alpha_{0, t}+\alpha_{1} \times \text { Guarantees }_{k, t}+\alpha_{2}^{\prime} \times \Delta(\text { Local Government Variables })_{k, t}+\varepsilon_{k, t}
$$

We perform the analysis first for the whole sample from the first quarter of 2005 to the last quarter of 2010. Afterward we perform the same analysis on sub-periods. These regressions are performed with time fixed effects.

$\Delta(\bullet)$ and $\% \Delta(\bullet)$ stand for first difference and percentage change of the variable over the quarter, respectively. $k$ is the index for countries and $t$ is the index for time. All

\begin{tabular}{|c|c|c|c|c|c|c|}
\hline Variable & $\begin{array}{l}\text { Q1 2005-Q4 } \\
2010\end{array}$ & $\begin{array}{l}\text { Q1 2005-Q4 } \\
2007\end{array}$ & $\begin{array}{l}\text { Q1 2008-Q4 } \\
2010\end{array}$ & $\begin{array}{c}\text { Time effects, } \\
\text { Q1 2005-Q4 } 2010\end{array}$ & $\begin{array}{l}\text { Time effects, } \\
\text { Q1 2005-Q4 } 2007\end{array}$ & $\begin{array}{l}\text { Time effects, } \\
\text { Q1 2008-Q4 } 2010\end{array}$ \\
\hline \multirow[t]{2}{*}{ Intercept } & 2.795 & -0.127 & 14.62 & $5.615^{* * *}$ & 0.244 & $15.73^{* * * *}$ \\
\hline & $(1.210)$ & $(-0.149)$ & $(1.456)$ & $(6.472)$ & $(0.226)$ & $(2.717)$ \\
\hline \multirow[t]{2}{*}{$\Delta($ S_IRN_REV) } & -5.598 & 0.250 & -5.919 & -4.892 & 0.215 & -5.793 \\
\hline & $(-1.405)$ & $(0.191)$ & $(-1.482)$ & $(-1.384)$ & $(0.126)$ & $(-1.420)$ \\
\hline \multirow[t]{2}{*}{ S_FDEF_GDP } & 2.127 & -0.109 & 2.906 & 3.204 & -0.129 & 2.946 \\
\hline & $(1.314)$ & $(-0.361)$ & $(1.140)$ & $(1.255)$ & $(-0.409)$ & $(1.084)$ \\
\hline \multirow[t]{2}{*}{$\Delta($ S_GEXT_L $)$} & $-7.103^{* * *}$ & 0.009 & $-11.25^{* *}$ & $-7.624^{* * *}$ & 0.000 & $-11.30^{* *}$ \\
\hline & $(-2.983)$ & $(0.056)$ & $(-2.365)$ & $(-2.650)$ & $(0.000)$ & $(-2.352)$ \\
\hline \multirow[t]{2}{*}{$\Delta\left(\mathrm{M} \_\mathrm{CA}\right)$} & $4.518^{*}$ & 0.002 & 1.932 & 3.694 & -0.148 & 1.932 \\
\hline & $(1.681)$ & $(0.003)$ & $(0.707)$ & $(1.546)$ & $(-0.193)$ & $(0.675)$ \\
\hline \multirow[t]{2}{*}{$\Delta$ (S_DEBT_GDP) } & $3.249^{* *}$ & 0.187 & 2.640 & $2.883^{* *}$ & 0.162 & 2.596 \\
\hline & $(2.504)$ & $(1.450)$ & $(1.584)$ & $(2.038)$ & (1.319) & $(1.332)$ \\
\hline \multirow[t]{2}{*}{ GUARANTEES } & $0.121^{*}$ & & $0.141^{* * * *}$ & 0.124 & & $0.144^{* *}$ \\
\hline & $(1.915)$ & & (2.699) & $(1.536)$ & & $(2.530)$ \\
\hline \multirow[t]{2}{*}{$\Delta($ B_CDS $) \times$ B_GDP } & $0.138^{* * *}$ & 0.033 & $0.105^{* * *}$ & $0.140^{* * *}$ & 0.054 & $0.106^{* * *}$ \\
\hline & $(2.713)$ & $(0.407)$ & $(2.618)$ & (3.313) & $(0.559)$ & $(2.629)$ \\
\hline Global variables \& CDS indices & Yes & Yes & Yes & & & \\
\hline With time fixed effects & & & & Yes & Yes & Yes \\
\hline Adjusted $R^{2}$ & 0.534 & 0.549 & 0.609 & 0.517 & 0.187 & 0.602 \\
\hline No. of observations & 382 & 195 & 187 & 382 & 195 & 187 \\
\hline
\end{tabular}
equations are estimated with 2SLS where the average leverage of the biggest banks is an instrument for $\Delta$ (B_CDS). The regressions are estimated with country fixed effects and robust standard errors. The standard errors are corrected for both heteroskedasticity and serial correlation.

*** Means significant at the $1 \%$ level.

** Means significant at the $5 \%$ level.

* Means significant at the $10 \%$ level.

\section{Table B.10}

Sovereign CDS is affected by bank exposures. Column I reports the coefficients and t-statistics for the sovereign panel regression including information about banks' assets:

$$
\begin{aligned}
& \left.\Delta\left(\mathrm{S}_{-} \mathrm{CDS}\right)_{k, t}=\alpha_{k, 0}+\alpha_{1}^{\prime} \times \Delta \text { (Domestic Variables }\right)_{k, t}+\alpha_{2}^{\prime} \times(\text { Explicit Guarantees })_{k, t} \\
& +\alpha_{3} \times \Delta\left(\text { B_BIS_CDS }_{k, t}+\alpha_{4}^{\prime} \times \Delta \text { (Local Bank Variables }\right)_{k, t} \\
& +\alpha_{5}^{\prime} \times \Delta(\text { Global Variables })_{t}+\alpha_{6} \times \Delta(\text { CDS Indices })_{t}+\varepsilon_{k, t}
\end{aligned}
$$

\begin{tabular}{|c|c|c|}
\hline Variable & I & II \\
\hline Intercept & $\begin{array}{c}-2.195 \\
(-0.683)\end{array}$ & $\begin{array}{c}4.529^{* * *} \\
(3.163)\end{array}$ \\
\hline$\Delta($ S_IRN_REV) & $\begin{array}{c}-8.324 \\
(-0.949)\end{array}$ & $\begin{array}{c}-8.333 \\
(-0.905)\end{array}$ \\
\hline S_FDEF_GDP & $\begin{array}{c}-1.648 \\
(-1.542)\end{array}$ & $\begin{array}{c}-2.121 \\
(-1.335)\end{array}$ \\
\hline$\Delta\left(\mathrm{S} \_\right.$GEXT_L $)$ & $\begin{array}{l}-7.799^{* *} \\
(-2.633)\end{array}$ & $\begin{array}{l}-7.877^{* *} \\
(-2.465)\end{array}$ \\
\hline$\Delta$ (M_CA) & 2.757 & 2.964 \\
\hline
\end{tabular}

Column II presents the results from the same regression but using time fixed effects instead of global variables and CDS indices.

$\Delta(\bullet)$ and $\% \Delta(\bullet)$ stand for first difference and percentage change of the variable over the quarter, respectively. $k$ is the index for countries and $t$ is the index for time. Country fixed effects and robust standard errors are used in all cases. The standard errors are corrected for both heteroskedasticity and serial correlation. 
Table B.10 (continued)

\begin{tabular}{|c|c|c|}
\hline Variable & I & II \\
\hline & $(1.314)$ & $(1.311)$ \\
\hline \multirow[t]{2}{*}{$\Delta\left(\mathrm{S} \_D E B T \_G D P\right)$} & $2.330^{* * * *}$ & $2.345^{* * * *}$ \\
\hline & $(6.358)$ & $(4.973)$ \\
\hline \multirow[t]{2}{*}{ GUARANTEES } & 0.056 & 0.065 \\
\hline & $(0.493)$ & $(0.587)$ \\
\hline \multirow[t]{2}{*}{$\Delta\left(E D F \_A L L\right)$} & $45.245^{* *}$ & $51.026^{* *}$ \\
\hline & $(2.073)$ & $(1.985)$ \\
\hline \multirow[t]{2}{*}{$\Delta\left(\mathrm{B} \_B I S \_C D S\right)$} & $0.366^{* * * *}$ & $0.424^{* * *}$ \\
\hline & $(2.842)$ & $(3.463)$ \\
\hline Global variables \& CDS indices & Yes & \\
\hline Time fixed effects & & Yes \\
\hline Adjusted $R^{2}$ & 0.583 & 0.578 \\
\hline No. of observations & 412 & 412 \\
\hline
\end{tabular}

*** Means significant at the $5 \%$ level.

** Means significant at the $1 \%$ level.

* Means significant at the $10 \%$ level.

\section{References}

Acharya, V.V., Steffen, S., 2015. The “greatest” carry trade ever? Understanding eurozone bank risks. J. Financ. Econ. 115 (2), $215-236$.

Acharya, V., Drechsler, I., Schnabl, P., 2015. A Pyrrhic victory? Bank bailouts and sovereign credit risk. J. Financ. 69 (6), 2689-2739.

Alter, A., Schüler, Y., 2012. Credit spread interdependencies of European states and banks during the financial crisis. J. Bank. Financ. 36 (12), $3444-3468$.

Ang, A., Longstaff, F.A., 2013. Systemic sovereign credit risk: lessons from the US and Europe. J. Monet. Econ. 60 (5), $493-510$.

Association for Financial Markets in Europe, 2011. Briefing on sovereign CDS, June. Joint AFME/ISDA/ICMA Paper.

Augustin, P., 2014. Sovereign credit default swap premia. J. Invest. Manag. forthcoming.

Bolton, P., Jeanne, O., 2011. Sovereign default risk and bank fragility in financially integrated economies. IMF Econ. Rev. 59 (2), $162-194$.

Crosbie, P., Bohn, J., 2003. Modeling default risk. Moody's KMV.

Degryse, H.,., Elahi, M.A., Penas, M.F., 2010. Cross-border exposures and financial contagion. Int. Rev. Financ. 10 (2), $209-240$.

Demirguc-Kunt, A., Detragiache, E., Merrouche, O., 2013. Bank capital: lessons from the financial crisis. J. Money, Credit, Bank. 45 (6).

Dieckmann, S., Plank, T., 2012. Default risk of advanced economies: an empirical analysis of credit default swaps during the financial crisis. Eur. Finan. Rev. $16,903$.

Dittmar, R., Yuan, K., 2008. Do sovereign bonds benefit corporate bonds in emerging markets. Rev. Financ. Stud. 21 (5), $1983-2014$.

Eichengreen, B., Mody, A., Nedeljkovic, M., Sarno, L., 2012. How the subprime crisis went global: evidence from bank credit default swap spreads. J. Int. Money Financ.

31 (5), 1299-1318.

Ejsing, J., Lemke, W., 2011. The Janus-headed salvation: sovereign and bank credit risk premia during 2008-2009. Econ. Lett. 110 (1), $28-31$.

Gennaioli, N., Martin, A., Rossi, S., 2014. Sovereign default, domestic banks, and financial institutions. J. Financ. 69 (2), $819-866$.

Gray, D.F., Merton, R.C., Bodie, Z., 2007. Contingent claims approach to measuring and managing sovereign credit risk. J. Invest. Manag. 5 (4), 1-24.

IMF, 2009. Fiscal implications of the global economic and financial crisis. IMF Staff Position Note No. 13.

IMF, 2010. Assessing proposals to ban naked shorts in sovereign credit default swap. Global Financial Stability Report, April.

IMF, 2013. Transition challenges to stability. Global Financial Stability Report, October.

Kallestrup, R., 2011. The importance of bank fundamentals for sovereign credit risk. Working Paper.

Kaminsky, G.L., Reinhart, C.M., Vegh, C.A., 2003. The unholy trinity of financial contagion. J. Econ. Perspect. 17 (4), $51-74$.

Klingler, S., Lando, D., 2015. Safe-haven CDS premia. Working Paper, Copenhagen Business School.

Longstaff, F., Pan, J., Pedersen, L.H., Singleton, K., 2011. How sovereign is sovereign credit risk? Am. Econ. J. Macroecon. 3 (2), $75-103$.

Reinhart, C.M., Rogoff, K.S., 2009. This Time Is Different: Eight Centuries of Financial Folly. Princeton University Press.

Reinhart, C.M., Rogoff, K.S., 2011. From financial crash to debt crisis. Am. Econ. Perspect. 101, 1676-1706.

Rose, A.K., Spiegel, M.M., 2010. Cross-country causes and consequences of the 2008 crisis: international linkages and American exposure. Pacific Economic Review 15(3). Blackwell Publishing, pp. 340-363.

Tressel, T., 2010. Financial contagion through bank deleveraging: stylized facts and simulations applied to the financial crisis. IMF Working Paper No. 236.

Yorulmazer, T., 2012. Has financial innovation made the world riskier? CDS, regulatory arbitrage and systemic risk. CDS, Regulatory Arbitrage and Systemic Risk (April $23,2013)$. 